\title{
Deletion of the Cold Thermoreceptor TRPM8 Increases Heat Loss and Food Intake Leading to Reduced Body Temperature and Obesity in Mice
}

\author{
Alfonso Reimúndez, ${ }^{1 *}$ Carlos Fernández-Peña, ${ }^{2 *}$ Guillermo García, ${ }^{1}$ CRubén Fernández, ${ }^{1}$ Purificación Ordás, ${ }^{2}$

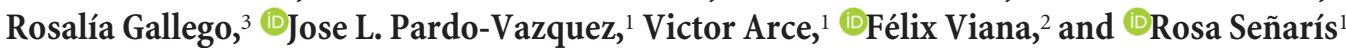 \\ 1Department of Physiology, Center for Research in Molecular Medicine and Chronic Diseases, University of Santiago de Compostela, 15782 Santiago de \\ Compostela, Spain, ${ }^{2}$ Institute of Neurosciences, Universidad Miguel Hernández-Consejo Superior de Investigaciones Científicas, 03550 San Juan de Alicante, \\ Spain, and ${ }^{3}$ Department of Morphological Sciences, University of Santiago de Compostela, 15782 Santiago de Compostela, Spain
}

The coupling of energy homeostasis to thermoregulation is essential to maintain homeothermy in changing external environments. We studied the role of the cold thermoreceptor TRPM8 in this interplay in mice of both sexes. We demonstrate that TRPM8 is required for a precise thermoregulation in response to cold, in fed and fasting. Trpm $8^{-/-}$mice exhibited a fall of $0.7^{\circ} \mathrm{C}$ in core body temperature when housed at cold temperatures, and a deep hypothermia $\left(<30^{\circ} \mathrm{C}\right)$ during food deprivation. In both situations, TRPM8 deficiency induced an increase in tail heat loss. This, together with the presence of TRPM8-sensory fibers innervating the main tail vessels, unveils a major role of this ion channel in tail vasomotor regulation. Finally, TRPM8 deficiency had a remarkable impact on energy balance. $\operatorname{Trpm} 8^{-/-}$mice raised at mild cold temperatures developed late-onset obesity and metabolic dysfunction, with daytime hyperphagia and reduction of fat oxidation as plausible causal factors. In conclusion, TRPM8 fine-tunes eating behavior and fuel utilization during thermoregulatory adjustments to mild cold. Persistent imbalances in these responses result in obesity.

Key words: food intake; fuel utilization; heat dissipation; obesity; thermoregulation; TRPM8

\section{Significance Statement}

The thermosensitive ion channel TRPM8 is required for a precise thermoregulatory response to cold and fasting, playing an important role in tail vasoconstriction, and therefore heat conservation, as well as in the regulation of ingestive behavior and metabolic fuel selection upon cooling. Indeed, TRPM8-deficient mice, housed in a mild cold environment, displayed an increase in tail heat loss and lower core body temperature, associated with the development of late-onset obesity with glucose and lipid metabolic dysfunction. A persistent diurnal hyperphagia and reduced fat oxidation constitute plausible underlying mechanisms in the background of a deficient thermoregulatory adjustment to mild cold ambient temperatures.

\section{Introduction}

Defending core body temperature (Tc) against environmental thermal challenges is a fundamental body homeostatic function.

Received 0ct. 18, 2017; revised Feb. 1, 2018; accepted Feb. 12, 2018.

Author contributions: R.S. and F.V. designed research; A.R., C.F.-P., G.G., R.F., P.O., and J.L.P.-V. performed research;A.R., C.F.-P.,P.O., R.G., G.G., R.F., J.L.P.-V., V.A., F.V., and R.S. analyzed data. R.S. and F.V.:Wrote the paper.

This work was supported by Project SAF2009-11175 and PI12/0058 to R.S., SAF2010-14990-R and SAF201677233-R to F.V., (Ministry of Economy and Competitiveness). European Regional Development Fund, and Severo Ochoa Programme for Centres of Excellence in R\&D SEV-2013-0317. C.F.-P. and P.0. held predoctoral fellowships of the Generalitat Valenciana (GRISOLIA/2008/025) and MINECO (BES-2011-047063), respectively. J.L.P.-V. received Human Frontier Science Program Long-Term Award LT000442/2012. We thank Luz Casas, Mireille Tora, Ana Miralles for excellent technical assistance and José Luis Otero for his help in statistical analysis.

The authors declare no competing financial interests.

${ }^{*}$ A.R. and C.F.-P. contributed equally to this study.

Correspondence should be addressed to Dr. Rosa Señarís, Department of Physiology, CIMUS, University of Santiago de Compostela, 15782 Santiago de Compostela, Spain. E-mail: rosa.senaris@usc.es.

DOI:10.1523/JNEUROSCI.3002-17.2018

Copyright $\odot 2018$ the authors $\quad 0270-6474 / 18 / 383643-14 \$ 15.00 / 0$
Despite large variations in ambient temperature, heat production balances heat loss, resulting in a stable Tc. To counteract the impact of external thermal changes on Tc, the CNS, mainly the preoptic area in the hypothalamus, receives and integrates thermal information from skin and visceral thermoreceptors providing command signals descending to peripheral effectors to evoke autonomic, somatic, hormonal, and behavioral responses (for review, see Morrison and Nakamura, 2011). The existence of temperature sensors also in the hypothalamus ensures an even more precise body temperature regulation (Song et al., 2016).

The first step in the thermoregulatory process is the detection of temperature changes by somatosensory nerve endings, a function ascribed to several members of the transient receptor potential (TRP) family of ion channels. The gating of these ion channels is strongly dependent on increases or decreases in temperature, which converts these proteins in key molecular thermosensors 
(Jordt et al., 2003; Dhaka et al., 2006; Caterina, 2007). The ion channel TRPM8 is a critical actor in the detection of cold temperatures (McKemy et al., 2002; Peier et al., 2002). TRPM8 is activated by moderate cooling and by cooling agents, such as menthol or icilin (McKemy et al., 2002; Peier et al., 2002), and it is expressed in a small subpopulation of trigeminal and DRG neurons. In addition to its clear role in cold thermosensation (Bautista et al., 2007; Colburn et al., 2007; Dhaka et al., 2007; McCoy et al., 2011), some studies have provided evidence supporting a role of TRPM8 in thermoregulation (Tajino et al., 2007, 2011; Almeida et al., 2012; Gavva et al., 2012).

In homeotherms, heat balance is linked to energy balance. Energy enters the body as food and leaves it as heat or external work. Basal metabolism and facultative (shivering) and adaptive (brown adipose tissue [BAT] activation) thermogenesis are the main heat-generating processes, which together with heat-conserving mechanisms (vasoconstriction and numerous behaviors) contribute to maintain homeothermy (Cannon and Nedergaard, 2009). Ambient temperatures below or above the thermoneutral zone increase energy expenditure (Cannon and Nedergaard, 2009). Indeed, the energetic cost of homeothermy is very high; almost $50 \%$ of the energy expenditure in a sedentary human is dedicated to maintain a constant Tc $\sim 37^{\circ} \mathrm{C}$ (Landsberg, 2012). This ability to preserve euthermia is critically dependent on robust connectivity between the thermoregulatory and the energy homeostasis systems, which permits the thermoregulatory imperative to be fulfilled without fluctuations in body fat stores that could compromise organismal survival. Nevertheless, the cellular and molecular mechanisms coupling the thermal balance and energy homeostasis are still poorly understood. We focused our study on the role of TRPM8 in the crosstalk between these two systems, considering thermoregulation as an integrated process in which the eating and metabolic response constitute a fundamental part of the thermal homeostasis. Taking into account the importance of ambient temperature and energy intake in thermoregulation, we studied a large group of mice exposed to a wide range of environmental temperatures, with different caloric intakes, and making a long-term follow up of their body weights and of their thermal and metabolic characteristics. We hypothesized that afferent thermal information from TRPM8 cold thermosensors is required in the coupling between thermoregulation and overall energy adjustments.

Using TRPM8-deficient mice (Trpm $8^{-/-}$) (Bautista et al., 2007) and mice in which the neurons expressing TRPM8 were ablated (Trpm8DTR ${ }^{+}$animals) (Pogorzala et al., 2013; Yarmolinsky et al., 2016), we demonstrated that this channel plays an important role in tuning the thermoregulatory response to cold, in fed and fasting. Indeed, TRPM8 activity is especially relevant to control the tail vasomotor tone. Furthermore, it is also required to transduce peripheral thermal information to adjust food consumption and substrate utilization to thermogenic needs in response to cooling. In the absence of TRPM8, mice developed obesity accompanied by metabolic alterations when raised at mild temperatures $\left(21^{\circ} \mathrm{C}-25^{\circ} \mathrm{C}\right)$, highlighting the relevance of this thermosensitive ion channel in the coupling between thermoregulation and energy homeostasis.

\section{Materials and Methods}

\section{Animals}

$\operatorname{Trpm} 8^{-1-}$ mice were generated by the laboratory of David Julius and obtained from The Jackson Laboratory (stock \#008198). Mice were maintained in heterozygosity by crossing to C57B6/J mice from Harlan Laboratories. Littermate wild-type (WT) mice were used as controls in all experiments. A BAC transgenic mouse line expressing the diphtheria toxin (DT) receptor fused with GFP under TRPM8 regulatory sequences $\left(\operatorname{Trpm} 8 D T R^{+}\right)$was generated in the laboratory of Mark Hoon and described previously (Pogorzala et al., 2013). The intraperitoneal treatment with DT (List Biological Laboratories, catalog \#150) for 7 consecutive days (200 ng dissolved in $0.9 \% \mathrm{NaCl}$ per day) resulted in the selective ablation of TRPM8-positive neurons. After treatment with DT, mice were allowed to recover for $7 \mathrm{~d}$. The effectiveness of the selective DTmediated ablation was determined by immunohistochemistry for GFP and RT-PCR for TRPM8 (data not shown). Littermate mice lacking the transgene $\left(\operatorname{Trpm} 8 D T R^{-}\right)$were also used as controls.

A BAC transgenic mouse line expressing eYFP under the TRPM8 promoter $\left(\operatorname{Trpm} 8-\mathrm{eYFP} \mathrm{P}^{+}\right)$was generated in the laboratory of Félix Viana (Morenilla-Palao et al., 2014).

After weaning, animals were housed at $21^{\circ} \mathrm{C}$ or $24^{\circ} \mathrm{C}-25^{\circ} \mathrm{C}$. Mice were always maintained in a cycle of $12 \mathrm{~h}$ light/ $12 \mathrm{~h}$ dark and had free access to fresh water and standard chow pellets.

All animal procedures were approved by the local Ethics Committee on Animal Care at the University of Santiago de Compostela and the University Miguel Hernández (Alicante), and were conducted in accordance to European guidelines.

\section{Body temperature and motor activity determination}

Tc and motor activity were measured using implantable radiotelemetric probes (G2 E-mitter series, MiniMitter, Starr Life Sciences; model ER4000) and a VitalView telemetry system. Probes were surgically implanted in the peritoneal cavity under general anesthesia with isoflurane. Animals recovered for $7 \mathrm{~d}$ in a room at $21^{\circ} \mathrm{C}, 12 \mathrm{~h}$ light $/ 12 \mathrm{~h}$ dark cycles with water and food ad libitum to ensure the absence of infection or fever. During recording of data, individual mice were positioned in plastic cages, with $\sim 5 \mathrm{~mm}$ of bedding, on individual telemetric receivers (ER4000, MiniMitter, Starr Life Sciences). Telemetric data from up to 8 mice of both genotypes were recorded simultaneously and collected every $30 \mathrm{~s}$ using VitalView software (Starr Life Sciences).

Rhythmometric analysis was performed by adjusting the data to a sigmoidal function as previously described with some modifications (Cornelissen, 2014). Using Origin 8.0 (Origin Lab), Tc raw data of each mouse were fitted to the following sinusoidal function and Midline Estimating Statistic of Rhythm and amplitude parameters were extracted as follows:

$$
y=y_{o}+A \cdot \operatorname{sen}\left(\frac{\pi(x-x c)}{(w)}\right)
$$

Where $y_{o}$ represents the Midline Estimating Statistic of Rhythm (MESOR), $A$ represents the amplitude, $x c$ represents phase shift, and $w$ represents $1 / 2$ period of the wave. Tc and motor activity results are shown as the mean of 5-7 d recording, calculated at 15 min intervals.

Protocol of cold experiments. Mice were housed at $29^{\circ} \mathrm{C}$ and $21^{\circ} \mathrm{C}$ for $7 \mathrm{~d}$ and at $17^{\circ} \mathrm{C}$ for $5 \mathrm{~d}$ while recording Tc and motor activity.

Protocol of the fasting experiment. Mice were maintained at $21^{\circ} \mathrm{C}$ and food-deprived for $24 \mathrm{~h}$, starting $3 \mathrm{~h}$ before the lights off, while recording Tc and motor activity.

Protocol of the experiment with CL-316243. Mice were maintained at $21^{\circ} \mathrm{C}$ and injected intraperitoneally with 0.1 or $1 \mathrm{mg} / \mathrm{kg} \mathrm{CL}-316243$ (CL). Tc was recorded for the following $6 \mathrm{~h}$. Mean change in Tc was measured between 1 and $6 \mathrm{~h}$ after administration.

\section{Body surface temperature by infrared (IR) thermography}

Body surface temperature was determined by IR thermography as an index of heat loss. Experimental animals were placed individually into a methacrylate enclosure with four identical compartments, allowing their simultaneous measurement. A high-resolution IR charge-coupled device camera (FLIR E60bx, FLIR Systems) was fixed $\sim 20 \mathrm{~cm}$ above the housing enclosure (zenithal view). Images were obtained every $60 \mathrm{~s}$ and analyzed using FLIR Tools software (FLIR Systems). We determined the surface temperatures of tail tip (Ttail), back skin (Ttrunk), and BAT $\left(\mathrm{T}_{\mathrm{BAT}}\right)$.

Protocol of the experiment in fed conditions at $21^{\circ} \mathrm{C}$ : Animals were maintained at a constant room temperature of $21^{\circ} \mathrm{C}$ for $24 \mathrm{~h}$. Food was available ad libitum. We measured number and duration of tail vasodilations, 
as well as the maximum and minimum values of Ttail in 10 min intervals during the light and dark phase. Ttrunk levels were expressed as the average of the back skin temperatures in 10 min intervals. $\mathrm{T}_{\mathrm{BAT}}$ was determined during ZT $8-9$ and expressed as the average of the maximum values of temperature observed in the interscapular skin.

Protocol of the fasting experiment. Animals were maintained in fasting for $24 \mathrm{~h}$ at a constant room temperature of $21^{\circ} \mathrm{C}$. Food pellets were removed $3 \mathrm{~h}$ before switching off the lights. Ttail was expressed as the average of the maximum levels in $10 \mathrm{~min}$ intervals. Ttail data were excluded when the tail was under the mouse body. Ttrunk levels were expressed as the average of the temperature levels in $10 \mathrm{~min}$ intervals.

Corporal measurements, body composition, and sample collection Body weight was monitored at varying intervals along 8-14 months. Body composition (fat and lean mass) was evaluated in live, conscious animals by quantitative nuclear magnetic resonance spectroscopy (EchoMRI 3-in-1 Animal Tissue Composition Analyzer; Echo Medical Systems). A system test was routinely performed at the beginning of each measurement day, and the equipment was calibrated by scanning a calibration holder containing a known amount of fat to test the validity of measurement.

Different fat depots (subcutaneous [sc], gonadal [g], interscapular [is], retroperitoneal [rp], mesenteric [m] WAT), interscapular BAT, and liver were removed and weighed. Thereafter, they were frozen or immersed in formaldehyde for histological analysis.

Blood was obtained by cardiac puncture, centrifuged, and the serum separated.

\section{Histological examinations of WAT and liver}

A portion of WAT from WT and TRPM8-deficient animals was routinely fixed (overnight in $4 \%$ buffered formaldehyde) and then paraffinembedded. Thereafter, $5-\mu \mathrm{m}$-thick sections were cut with a microtome and placed on Superfrost Plus slides (Thermo Scientific). Slides were then stained with hematoxylin and eosin, according to standard laboratory protocols. Liver frozen sections $(8 \mu \mathrm{m})$ were cut and stained in filtered oil red for $10 \mathrm{~min}$. Sections were washed in distilled water, counterstained with Mayers hematoxylin for $3 \mathrm{~min}$.

Immunohistochemistry of GFP in DRG sections from Trpm8DTR mice and in tail sections from Trpm8-eYFP ${ }^{+}$mice

Trpm8DTR ${ }^{+}$adult mice treated with DT or vehicle (nontreated) and Trpm8-eYFP ${ }^{+}$adult mice were perfused with $4 \%$ PFA. The DRGs in the first case and the distal part of the tail in the second case were dissected, postfixed with $4 \%$ PFA for $3-4 \mathrm{~h}$ at $4^{\circ} \mathrm{C}$, and left in PBS at $4^{\circ} \mathrm{C}$ until they were processed. Before sectioning, the tissue was embedded in CryoGlue medium (Slee Medical) and quickly frozen on dry ice. Cryostat sections (20-30 $\mu \mathrm{m}$ thick) were adhered to slides (Superfrost Plus, Thermo Scientific).

The following day, sections were rinsed in phosphate buffer with Tween (PBT, $0.1 \mathrm{M}$ phosphate buffer, $0.05 \%$ Tween 20, pH 7.4), twice, during $10 \mathrm{~min}$, and then incubated in blocking buffer solution (BB, 5\% BSA in PBT containing $1 \%$ Triton X-100) for $1 \mathrm{~h}$ at room temperature. Next, the BB was replaced by the primary antibody solution: chicken anti-GFP antibody (Abcam, ab13970) in BB (1:2000) in the case of DRGs; in the tail samples, the same antibody and the same dilution were used in BB, in combination with rabbit anti-CGRP antibody (Millipore, CP205L,1:2000), or rabbit anti-TH antibody (Pel Freez, P4010, 1:1000). In both cases, tissue sections were incubated with the antibodies overnight at $4^{\circ} \mathrm{C}$.

Thereafter, the slides were washed four times during 15 min with PBT and incubated in the secondary antibody solution containing goat antichicken Alexa-488 (Invitrogen, A11039, 1:1000), diluted in BB in the case of DRGs ( $2 \mathrm{~h}$ at room temperature); and goat anti-rabbit Alexa-596 antibody (Invitrogen, A11012, 1:1000) and goat anti-chicken Alexa-488 antibody (Invitrogen, A11039, 1:1000), diluted in BB in the case of tail ( $2 \mathrm{~h}$ at room temperature). Afterward, they were washed four times during $15 \mathrm{~min}$ with PBT and incubated in nuclear staining solution $(0.5$ $\mu \mathrm{g} / \mathrm{ml}$ Hoechst 33342, Invitrogen, H1399) in PBS, pH 7.4, during 5 min. Finally, the samples were mounted with Fluoromount Aqueous Mounting Medium (Sigma-Aldrich). All washes were made in gentle agitation at room temperature, and after the addition of the secondary antibody solution the process was protected from light.

\section{Serum analysis}

Serum leptin (Quantikine Immunoassay, R\&D Systems) and insulin (Millipore) were determined in WT and Trpm $8^{-/-}$mice. Both groups of mice were subjected to a glucose tolerance test after an overnight fast (food was removed at 19:00 p.m.), and glucose was administered soon after lights on at 8:00 a.m. A bolus of glucose was given $(1 \mathrm{~g} / \mathrm{kg}$, i.p.), and blood was sampled from the tail vein. Glucose levels were read using a glucometer, beginning before the injection of glucose and continuing at 30, 60, and $120 \mathrm{~min}$. Comparisons at each time point between control and $\operatorname{Trp} m 8^{-/-}$mice were used for statistical significance.

\section{Analysis of energy expenditure (EE), food intake, respiratory} quotient (RQ), and ambulatory activity in metabolic cages

Age- and gender-matched control and TRPM8-deficient mice were acclimated to metabolic cages for $2 \mathrm{~d}$ before data collection at room temperature $\left(21^{\circ} \mathrm{C}\right)$ and recorded over another $3 \mathrm{~d}$. Total oxygen consumption $\left(\mathrm{VO}_{2}\right)$ and carbon dioxide production $\left(\mathrm{VCO}_{2}\right)$ were measured continuously by indirect calorimetry and recorded every $20 \mathrm{~min}$ (LabMaster multipurpose screening system; TSE Systems). $\mathrm{VO}_{2}$ was converted to individual total EE by TSE Software. EE was expressed as $\mathrm{kcal} / \mathrm{kg}$ in $24 \mathrm{~h}$ (total), in $12 \mathrm{~h}$ of daytime (day) or $12 \mathrm{~h}$ of night-time (night).

$R Q$. The RQ is the ratio of carbon dioxide output $\left(\mathrm{VCO}_{2}\right)$ to oxygen uptake $\left(\mathrm{VO}_{2}\right)$, that is as follows: $\mathrm{RQ}=\mathrm{VCO}_{2} / \mathrm{VO}_{2}$. The RQ was calculated both during the light and dark phase.

Food intake was continuously recorded. Standard chow was available ad libitum.

Ambulatory activity was determined simultaneously with the collection of indirect calorimetry data. Consecutive adjacent IR beam breaks in either the $x$ or $z$ axes (i.e., in the horizontal plane) were scored as an activity count and a tally recorded every $20 \mathrm{~min}$.

\section{Food intake experiments in mice at different temperatures}

WT and Trpm $8^{-1-}$ mice were individually housed in a room with controlled-ambient temperature. Room temperature was set at $17^{\circ} \mathrm{C}$, $21^{\circ} \mathrm{C}, 25^{\circ} \mathrm{C}$, and $29^{\circ} \mathrm{C}$ for $7 \mathrm{~d}$. Mice were maintained in a cycle of $12 \mathrm{~h}$ light $/ 12 \mathrm{~h}$ dark and had free access to fresh water and standard chow pellets. Food pellets were weighed every day at 8 a.m. and 8 p.m. to check daytime and night-time changes.

\section{Experimental design and statistical analysis}

Data are presented as mean \pm SEM. $n$ represents the number of mice per group. For randomization, predefined numbers were assigned to each treatment group. The different experimental groups were processed identically throughout the whole experiment. Outliers were not discarded unless there was independent evidence that the result was incorrect.

Statistical calculations were performed using the Statistical Package for Social Sciences (IBM) software and MATLAB (The MathWorks). Before all statistical analyses, data were examined for assumptions of normality and equality of variance using the Kolmogorov-Smirnov test, followed by the Levene test. For the analysis of Tc, motor activity, and $\mathrm{VO}_{2}$, we used ANOVA for repeated measures or for independent samples, as required, followed by Bonferroni test. When group variances were not similar, as it happened with body weight curves, we used the nonparametric Fisher's exact permutation test (MATLAB). Day/night results of food intake, RQ, insulin, cholesterol, and leptin levels were analyzed by two-way ANOVA with genotype and time as main factors. A post hoc Bonferroni test was performed when there was a significant interaction between both main factors. Statistical significance between two groups was determined by an unpaired $t$ test or $t$ test for nonindependent samples, as needed. When sample size was small or data were nonparametric, as in the case of Ttail, Ttrunk, and $\mathrm{VO}_{2}$ analysis, we used a Fisher's exact permutation test (MATLAB).

\section{Results}

\section{Lack of TRPM8 impairs the maintenance of Tc in cold environments}

To examine the role of TRPM8 in thermoregulation, we recorded continuously $\mathrm{Tc}$ in male mice housed in light-dark conditions 

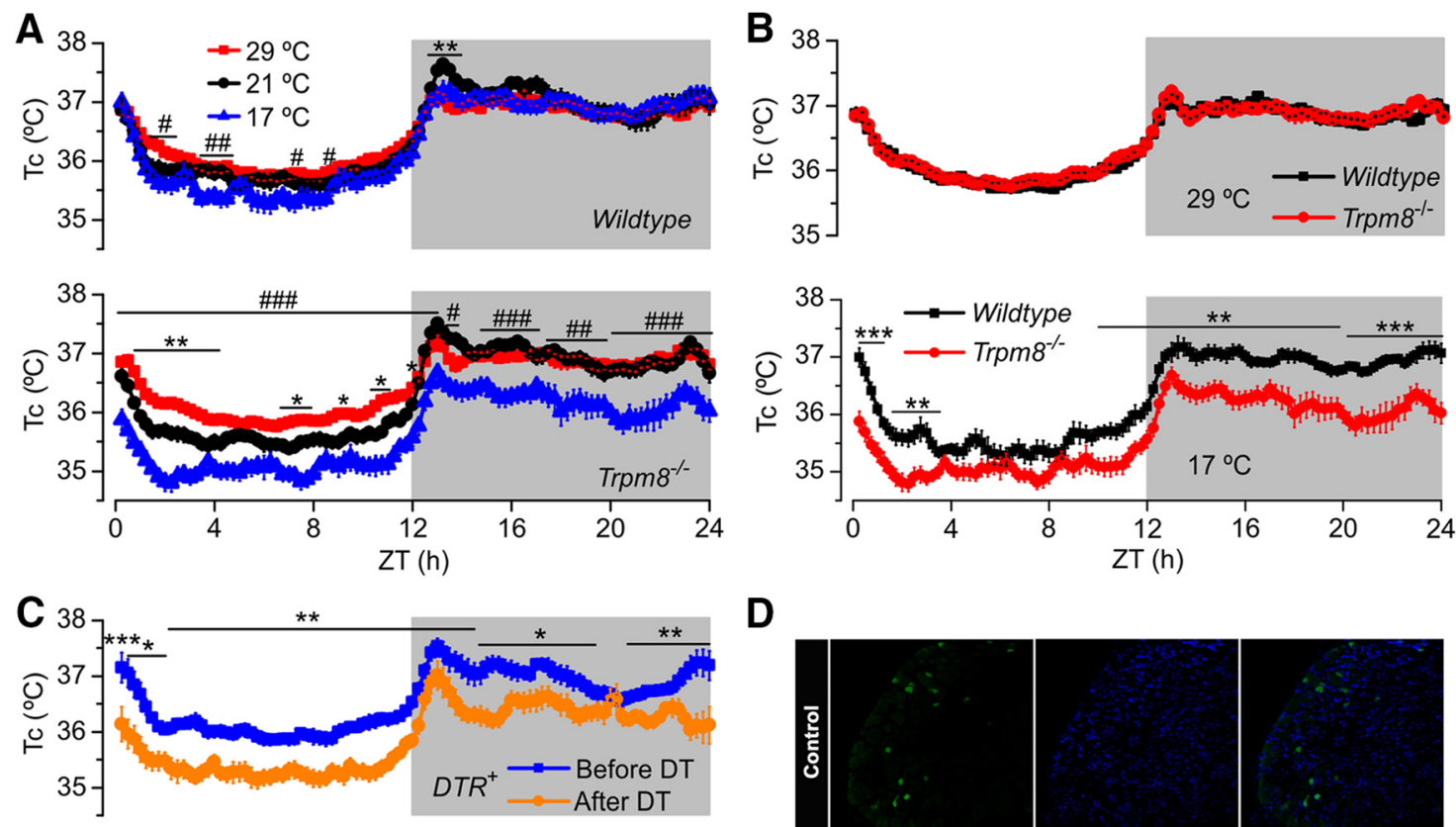

D
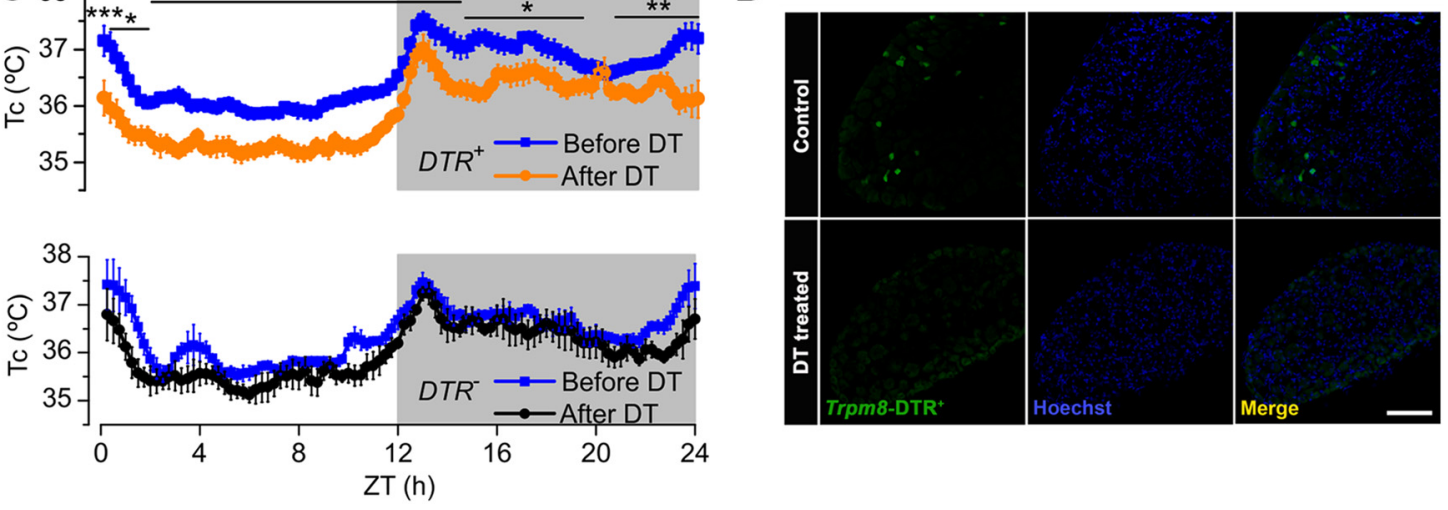

Figure 1. Mild hypothermia in Trpm $8^{-1-}$ and Trpm8DTR ${ }^{+}$mice when exposed to cold temperatures. Continuous telemetric recordings of Tc. Gray and white bars represent night and day, respectively. $A$, Superimposed records of $T$ c in mice exposed to ambient temperatures of $29^{\circ} \mathrm{C}$ for $7 \mathrm{~d}, 21^{\circ} \mathrm{C}$ for $7 \mathrm{~d}$, and $17^{\circ} \mathrm{C}$ for $5 \mathrm{~d}$. Average of the Tc values obtained during the $5-7 \mathrm{~d}$ of recording. ${ }^{*} 29$ vs $21^{\circ} \mathrm{C}$. ${ }^{\prime \prime} 29$ vs $17^{\circ} \mathrm{C}$. ${ }^{*}$ or ${ }^{\#} p<0.05,{ }^{* *}$ or ${ }^{\# \#} p<0.01,{ }^{* * *}$ or ${ }^{\# \# \#} p<0.001$. WT: $29^{\circ} \mathrm{C}, n=13 ; 21^{\circ} \mathrm{C}, n=14 ; 17^{\circ} \mathrm{C}, n=11 . \mathrm{K} 0: 29^{\circ} \mathrm{C}, n=12 ; 21^{\circ} \mathrm{C}, n=14 ; 17^{\circ} \mathrm{C}, n=13$. Repeated-measures ANOVA and Bonferroni test. $p$ values indicate significance of the post hoc test. $B$, WT and $7 r p m 8^{-/-}$mice were housed at $29^{\circ} \mathrm{C}$ for $7 \mathrm{~d}$ (top) or $17^{\circ} \mathrm{C}$ for $5 \mathrm{~d}$ (bottom). Average of 7 or $5 \mathrm{~d} \mathrm{Tc} \mathrm{record,}$ respectively. ${ }^{* *} p<0.01,{ }^{* * *} p<0.001$ (repeated-measures ANOVA and Bonferroni test). $p$ values indicate significance of the post hoc test. WT, $n=11 ; \mathrm{KO}, n=13 . \mathrm{C}$, Trpm8DTR $^{+}$(top) and Trpm8DTR $^{-}$(bottom) mice housed at $21^{\circ} \mathrm{C}$ before (Before DT) and 1 week after intraperitoneal treatment with DT (After DT). The $200 \mathrm{ng}$ of DT in $100 \mu \mathrm{L} \mathrm{of} 0.9 \% \mathrm{NaCl}$ for $7 \mathrm{~d}$. Average of $7 \mathrm{~d} \mathrm{Tcrecord}$. ${ }^{*} p<0.05$, ${ }^{* *} p<0.01,{ }^{* * *} p<0.001$ (repeated-measures ANOVA and Bonferroni test). $n=7$ mice/group. $p$ values indicate significance of the post hoc test. $D$, Representative GFP immunohistochemistry in DRG sections from Trpm8DTR ${ }^{+}$mice after treatment with DT (DT treated) or vehicle (control). Scale bar, $100 \mu \mathrm{m}$. There is complete absence of GFP labeling after DT treatment. All experiments were performed in male mice ( $3-5$ months of age). Data are mean \pm SEM.

Table 1. Characteristics of Tc in wild-type and Trpm $8^{-/-}$mice exposed to different environmental temperatures ${ }^{a}$

\begin{tabular}{|c|c|c|c|c|}
\hline Parameter & Genotype & $29^{\circ} \mathrm{C}$ & $21^{\circ} \mathrm{C}$ & $17^{\circ} \mathrm{C}$ \\
\hline \multirow[t]{2}{*}{ MESOR $\left({ }^{\circ} \mathrm{C}\right)$} & $W T$ & $36.4 \pm 0.00$ & $36.4 \pm 0.1$ & $36.3 \pm 0.1$ \\
\hline & $\operatorname{Trpm} 8^{-/-}$ & $36.5 \pm 0.05$ & $36.2 \pm 0.05$ & $\begin{array}{l}35.6 \pm 0.1^{* * *}, \# \# \# \\
\left(p=0.000004 \text { vs } 29^{\circ} \mathrm{C}\right) \\
\left(p=0.0005 \text { vs } 21^{\circ} \mathrm{C}\right)\end{array}$ \\
\hline \multirow[t]{2}{*}{ Amplitude $\left({ }^{\circ} \mathrm{C}\right)$} & $W T$ & $0.6 \pm 0.00$ & $\begin{array}{l}0.8 \pm 0.00^{* *} \\
(p=0.001)\end{array}$ & $\begin{array}{l}0.9 \pm 0.1^{* * *} \\
(p=0.0002)\end{array}$ \\
\hline & $\operatorname{Trpm} 8^{-/-}$ & $0.6 \pm 0.04$ & $\begin{array}{l}0.9 \pm 0.03^{* * *} \\
(p=0.00009)\end{array}$ & $\begin{array}{l}0.8 \pm 0.1^{*} \\
(p=0.010)\end{array}$ \\
\hline
\end{tabular}

${ }^{a}$ MESOR and amplitude of Tc in WT and Trpm8 ${ }^{-/-}$male mice exposed to different environmental temperatures for $5-7 \mathrm{~d}$. Tc values were adjusted to a sinusoidal function, as described by Cornelissen (2014). Data are mean \pm SEM. Mice were males of $3-5$ months of age.

${ }^{*} p<0.05$ (vs $29^{\circ} \mathrm{C}$ ); ${ }^{* *} p<0.01$ (vs $29^{\circ} \mathrm{C}$ ); ${ }^{* * *} p<0.001$ (vs $29^{\circ} \mathrm{C}$ ). ${ }^{\# \#} p<0.001\left(21^{\circ} \mathrm{C}\right.$ vs $17^{\circ} \mathrm{C}$ ); repeatedmeasures ANOVA and Bonferroni test. WT: $29^{\circ} \mathrm{C}, n=13 ; 21^{\circ} \mathrm{C}, n=14 ; 17^{\circ} \mathrm{C}, n=11 . \mathrm{K} 0: 29^{\circ} \mathrm{C}, n=12 ; 21^{\circ} \mathrm{C}, n=$ $14 ; 17^{\circ} \mathrm{C}, n=13$.

and exposed for 5-7 $\mathrm{d}$ to a range of environmental temperatures $\left(29^{\circ} \mathrm{C}, 21^{\circ} \mathrm{C}\right.$, and $\left.17^{\circ} \mathrm{C}\right)$ (Fig. $1 A$ ). Tc showed regular circadian oscillations, with elevations during the dark phase in all temperatures evaluated. At $29^{\circ} \mathrm{C}$ (thermoneutrality), there was no difference in Tc between WT and Trpm $8^{-/-}$mice (Fig. 1B; Table 1).
Table 2. Characteristics of Tc in $\operatorname{Trpm}_{8 \mathrm{DTR}}{ }^{+}$mice housed at $21^{\circ} \mathrm{C}^{a}$

\begin{tabular}{lll}
\hline Parameter & Before DT treatment & After DT treatment \\
\hline MESOR $\left({ }^{\circ} \mathrm{C}\right)$ & $36.6 \pm 0.1$ & $35.8 \pm 0.1^{* * *}$ \\
Amplitude $\left({ }^{\circ} \mathrm{C}\right)$ & $0.6 \pm 0.1$ & $0.7 \pm 0.1, p=0.08$ \\
\hline
\end{tabular}

$\overline{{ }^{a} \text { MESOR and amplitude of Tc in } \operatorname{Trpm} 8 \mathrm{DTR}{ }^{+} \text {male mice housed at } 21^{\circ} \mathrm{C} \text { for } 7 \mathrm{~d} \text {, before and after DT treatment. Tc }}$ values were adjusted to a sinusoidal function, as described by Cornelissen (2014). Data are mean \pm SEM. Mice were males of 3-5 months of age.

${ }^{* * *} p=0.0001$ (Student's $t$ test for nonindependent samples); $n=7$.

In WT mice, Tc values were almost unchanged when environmental temperature was lowered to $21^{\circ} \mathrm{C}$ or to $17^{\circ} \mathrm{C}$, although a slight increase in the amplitude of oscillations was observed (Fig. $1 A$; Table 1 ). In contrast, Tc decreased significantly in TRPM8deficient mice during environmental cold exposure. At $21^{\circ} \mathrm{C}$, mutant animals exhibited drops of Tc during the day and at $17^{\circ} \mathrm{C}$ their average daily $\mathrm{Tc}$ was $\sim 0.7^{\circ} \mathrm{C}$ lower than WT littermates, during light and dark phases (Fig. $1 A, B$; Table 1 ). The amplitude of the oscillations increased in these mice similarly to control counterparts.

To further validate the relevance of TRPM8 channels in coldinduced thermoregulation, we used Trpm8DTR ${ }^{+}$mice (Pogorzala et al., 2013), animals in which TRPM8-expressing neurons 

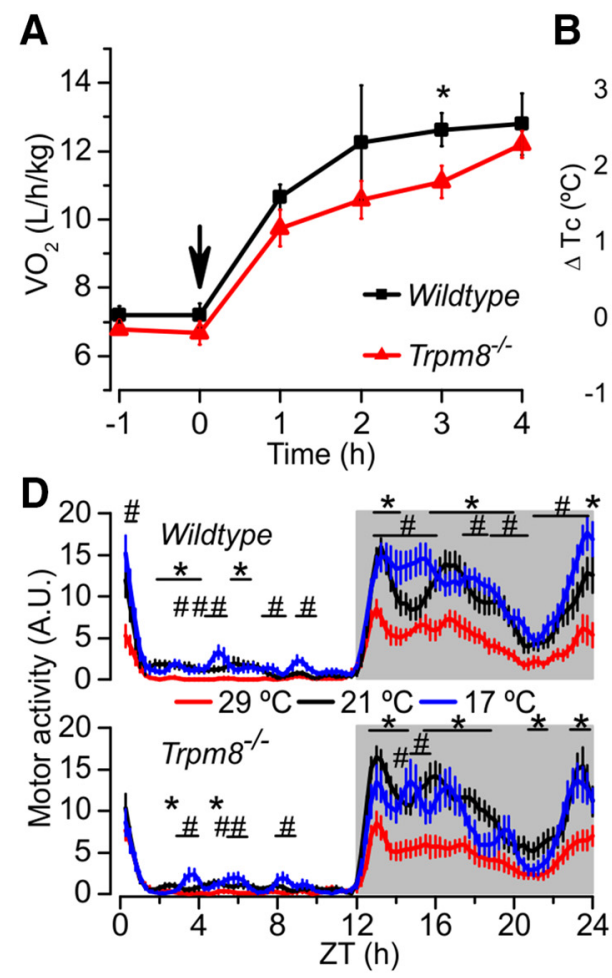

B

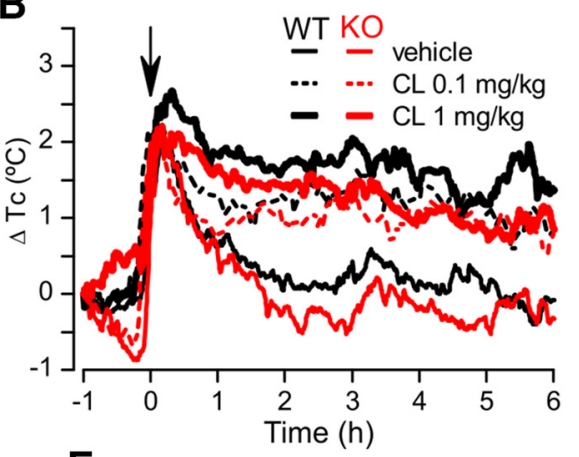

E

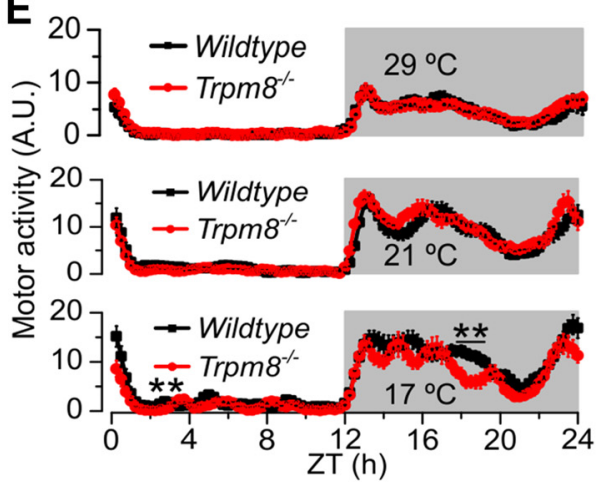

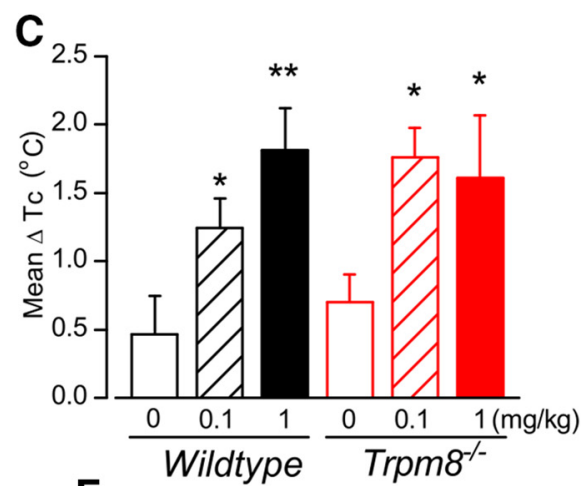

F

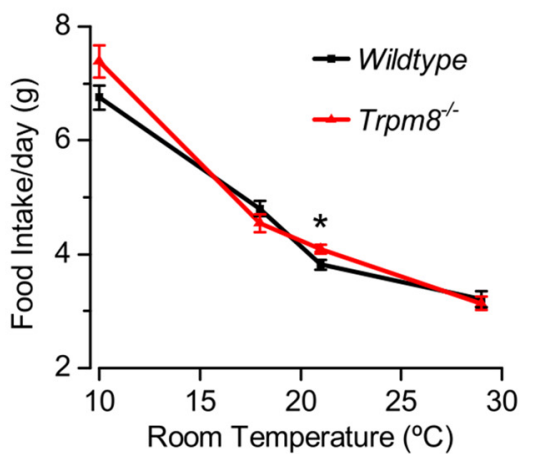

Figure 2. BAT functionality and other thermogenic mechanisms are conserved in Trpm $8^{-/-}$mice. $A, V_{2}$ determined in metabolic cages before and after an intraperitoneal injection of the $\beta 3$-adrenergic agonist CL-316243 (CL, $1 \mathrm{mg} / \mathrm{kg}$ ) in WT and Trpm $8^{-/-}$mice housed at $21^{\circ} \mathrm{C} . n=4$ WT and $5 \mathrm{KO}$ mice. ${ }^{*} p=0.03$ (Student's $t$ test). $B, C$, Effect of the $\beta 3$-adrenergic receptor agonist CL-316243 (CL, 0.1 and $1 \mathrm{mg} / \mathrm{kg}$, i.p.) on Tc in WT and Trpm $8^{-/-}$(KO) mice housed at $21^{\circ} \mathrm{C}$. Continuous recording of Tc, displayed as mean increase in temperature over Tc basal levels after the injection of CL. Arrow points to the moment of injection. Histograms represent the mean change in Tc measured between 1 and $6 \mathrm{~h}$ after administration. ${ }^{*} p<0.05,{ }^{* *} p<0.01$. WT: $p=0.043$ and $p=0.007 ; \mathrm{KO}: p=0.022$ and $p=0.044$ (two-way ANOVA followed by Bonferroni). The factor "treatment" was statistically significant. $n=3$ WT and 4 KO mice. $\boldsymbol{D}, \boldsymbol{E}$, Recordings of motor activity by telemetry using implanted probes. Gray and white bars as in Figure $1 . D$, Superimposed plots of motor activity in mice exposed to ambient temperatures of $29^{\circ} \mathrm{C}$ for $7 \mathrm{~d}, 21^{\circ} \mathrm{C}$ for $7 \mathrm{~d}$, and $17^{\circ} \mathrm{C}$ for 5 d. Average of activity values. ${ }^{*} 29^{\circ} \mathrm{C}$ vs $21^{\circ} \mathrm{C} ;{ }^{\#} 29^{\circ} \mathrm{C}$ vs $17^{\circ} \mathrm{C} ;{ }^{*}$ or ${ }^{\#} p<0.05 ;{ }^{* *}$ or ${ }^{\# \#} p<0.01 ;{ }^{* * *}$ or ${ }^{\# \# \#} p<0.001$; (repeated-measures ANOVA and post hoc Bonferroni test). $p$ values indicate significance of the post hoc test. WT: $29^{\circ} \mathrm{C}, n=13 ; 21^{\circ} \mathrm{C}, n=14 ; 17^{\circ} \mathrm{C}, n=11 . \mathrm{KO}: 29^{\circ} \mathrm{C}, n=12 ; 21^{\circ} \mathrm{C}, n=14 ; 17^{\circ} \mathrm{C}, n=13 . \boldsymbol{E}$, WT and $\operatorname{Trpm} 8^{-/-}$mice were housed at $29^{\circ} \mathrm{C}$ for $7 \mathrm{~d}$ (top), $21^{\circ} \mathrm{C}$ for $7 \mathrm{~d}$ (middle), and at $17^{\circ} \mathrm{C}$ for $5 \mathrm{~d}$ (bottom). Average of 7 or $5 \mathrm{~d}$ activity record is shown. WT, $n=13 ; \mathrm{KO}, n=12$. F, Daily food intake (average of 1 week) of WT and Trpm $8^{-/-}$mice housed at $29^{\circ} \mathrm{C}, 21^{\circ} \mathrm{C}, 17^{\circ} \mathrm{C}$, and $10^{\circ} \mathrm{C}$ for $7 \mathrm{~d}$. ${ }^{*} \mathrm{P}=0.03$ vs WT (Student's $t$ test). WT: $29^{\circ} \mathrm{C}, 21^{\circ} \mathrm{C}, 17^{\circ} \mathrm{C}, n=9 ; 10^{\circ} \mathrm{C}, n=6 . \mathrm{K} 0: 29^{\circ} \mathrm{C}, 21^{\circ} \mathrm{C}, 17^{\circ} \mathrm{C}, n=8 ; 10^{\circ} \mathrm{C}, n=4$. All experiments were performed in male mice of $3-6$ months of age. Data are mean \pm SEM.

were ablated after treatment with DT. The loss of TRPM8-positive cells was demonstrated by immunohistochemistry ( $8.7 \pm 1.6 \mathrm{GFP}-$ positive cells/section, $n=3$ vehicle-treated mice vs $0 \pm 0, n=4$ DT-treated mice; Fig. 1D) and RT-PCR (data not shown). This animal model allowed us to study the acute effects of TRPM8 removal. As shown in Figure $1 C$ (top) and Table 2, DT treatment $(200 \mathrm{ng} / 100 \mu \mathrm{L})$ of $\operatorname{Trpm} 8 \mathrm{DTR}{ }^{+}$mice housed at $21^{\circ} \mathrm{C}$ decreased their average $\mathrm{Tc} \sim 0.7^{\circ} \mathrm{C}$. The lack of off-target effects of DT treatment on thermoregulation was demonstrated by administering the same dose of DT to littermates not carrying the transgene (Trpm8DTR ${ }^{-}$mice). No significant changes in Tc were observed in these mice (Fig. $1 C$, bottom).

\section{TRPM8-deficient mice present a functional BAT and}

maintain the locomotor and food intake responses to cooling To better understand the factors involved in the altered thermoregulation due to TRPM8 deficiency, we evaluated the response of heat-generating mechanisms in control and Trpm8-knock-out (KO) mice.

Heat production by BAT through stimulation of its sympathetic innervation is a main thermoregulatory response to cold in rodents. To test the functionality of BAT, we measured the effect of CL-316243 (CL), a specific $\beta 3$-adrenergic receptor ( $\beta 3$-AR) agonist on $\mathrm{Tc}$ and $\mathrm{VO}_{2}$ in mice housed at $21^{\circ} \mathrm{C}$. CL treatment induced a twofold increase in $\mathrm{VO}_{2}$ (Fig. $2 \mathrm{~A}$ ) accompanied by a rise of $\sim 1^{\circ} \mathrm{C}$ in Tc (Fig. $2 \mathrm{~B}, \mathrm{C}$ ) in both WT and Trpm $8^{-/-}$mice, demonstrating a normal response of BAT to $\beta 3$-AR activation in the absence of TRPM8.

Increased motor activity is another behavioral thermoregulatory response to cold (Terrien et al., 2011). We evaluated the influence of exposure to different ambient temperatures on motor activity using the same telemetric probe implanted for Tc measures, recording both parameters simultaneously under the same environmental conditions. As expected, locomotor activity increased as ambient temperature dropped (Fig. 2D). Moreover, these changes were nearly identical in WT and $\operatorname{Trpm} 8^{-1-}$ mice (Fig. 2E).

Ambient cooling also leads to an increase in food intake to match the greater thermoregulatory demands (Melnyk and HimmsHaggen, 1998; Terrien et al., 2011; Abreu-Vieira et al., 2015; Kaiyala et al., 2015). As expected, a stepwise reduction in housing temperature (from $29^{\circ} \mathrm{C}$ to $10^{\circ} \mathrm{C}, 7 \mathrm{~d}$ at each temperature) led to a concomitant increase in food intake in WT mice. A similar pattern was observed in the absence of TRPM8 (Fig. 2F). Interestingly, $\operatorname{Trpm} 8^{-/-}$mice displayed a small but significant increase in the levels of food intake/d in relation to WT littermates when maintained at a temperature of $21^{\circ} \mathrm{C}(p<0.05)$ (Fig. $\left.2 F\right)$.

Collectively, these results suggest the presence of other thermal sensors in addition to TRPM8 activating the main heat- 

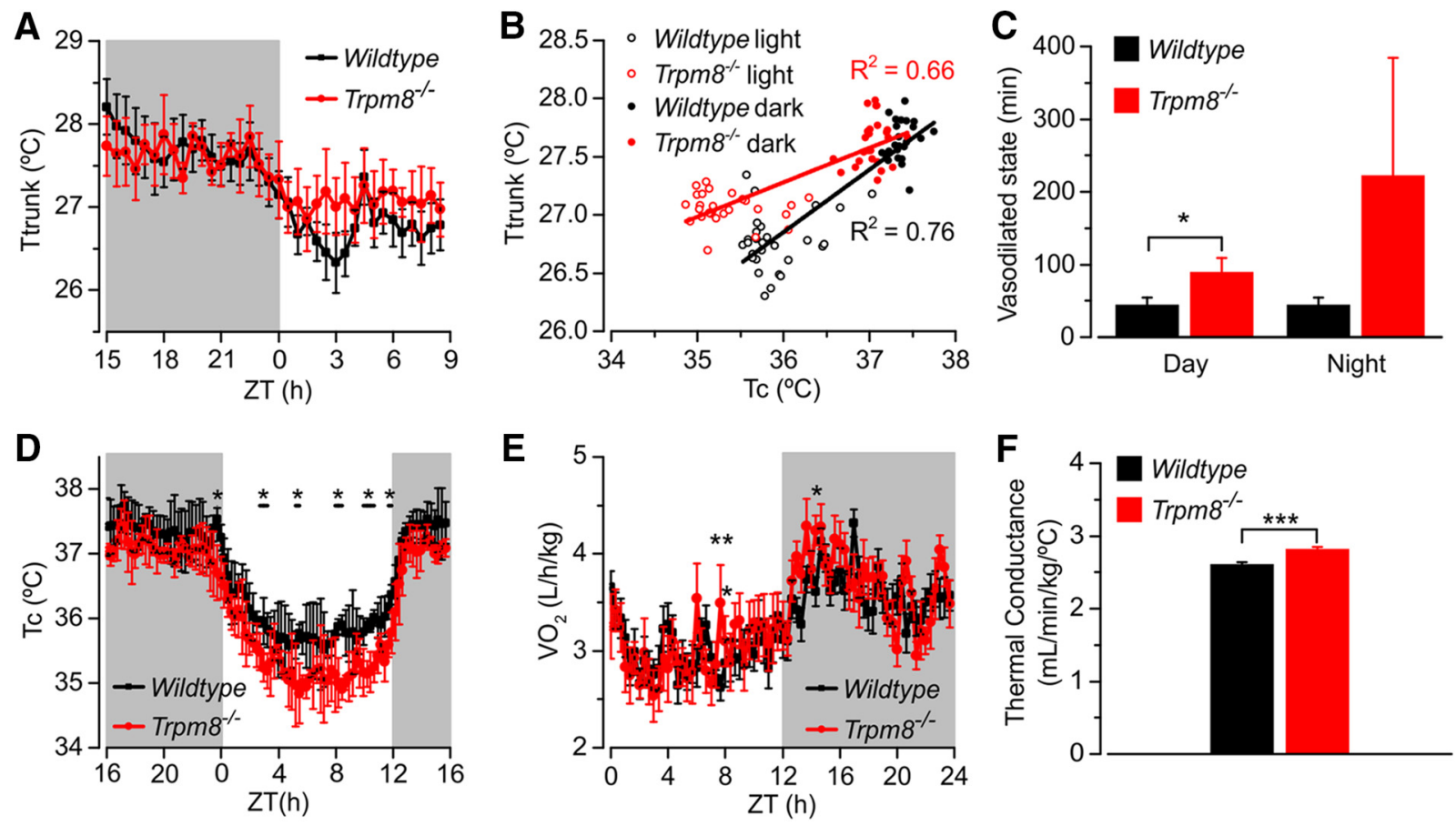

Figure 3. Tail heat loss is increased in Trpm $8^{-1-}$ mice. $A$, Ttrunk determined by IR thermography. Values indicate the average of the maximum levels of the Ttrunk in $10 \mathrm{~min}$ intervals. $n=5 \mathrm{WT}$ and $3 \mathrm{KO}$ mice. $\boldsymbol{B}$, Relation between Tc and Ttrunk in WT and Trpm $8^{-1-}$ mice in dark and light phases. Each point represents the average over 20 min. $n=5 \mathrm{WT}$ and $3 \mathrm{KO}$ mice. A linear regression line is shown for each genotype. C, Total time that the tail spent vasodilated during the light and dark phase. ${ }^{*} p=0.04$ (two-way ANOVA followed by Bonferroni). $n=5 \mathrm{WT}$ and $3 \mathrm{KO}$ mice. $\boldsymbol{D}$, Average Tc recorded for $7 \mathrm{~d}$ in WT and Trpm $8^{-1-}$ mice. WT, $n=5 ; \mathrm{KO}, n=3 .{ }^{*} p<0.05$ (Fisher's exact permutation test). $E$, V0 ${ }_{2}$ determined in WT and Trpm $8^{-1-}$ mice using metabolic cages for $48 \mathrm{~h} .{ }^{*} p<0.05,{ }^{* *} p<0.01$ (Fisher's exact permutation test). $n=6$ mice/group. $F$, Whole-body thermal conductance determined as V0 $/\left(\mathrm{Tc}-\mathrm{Ta}\right.$ ) in a period of $24 \mathrm{~h} .{ }^{* * *} p=0.00003$ (Student's $t$ test). $n=6$ mice/group. Grey and white bars as in Figure 1. All experiments were performed in male mice of $7-8$ months of age at an ambient temperature of $21^{\circ} \mathrm{C}$. Data are mean \pm SEM.

producing thermoregulatory responses to environmental cooling and therefore preventing great drops in Tc.

$\operatorname{Trpm} 8^{-/-}$mice exhibit an increased tail heat loss

Next, we evaluated the response of heat-conserving mechanisms during cooling in unrestrained WT and Trpm $m 8^{-/-}$mice, using IR thermography to measure skin temperature. As an index of vasomotor regulation and heat loss, we measured surface temperature of the back skin (Ttrunk), useful for detecting heat leaks (Meyer et al., 2017) and of the tail skin (Ttail), the major heat-exchange organ in rodents (Young and Dawson, 1982; Hosono et al., 2001). We studied Ttrunk in mice housed at $21^{\circ} \mathrm{C}$ for $24 \mathrm{~h}$ (night and day). We were unable to find significant differences between both genotypes, although a tendency to higher Ttrunk levels was observed in $\operatorname{Trpm} 8^{-/-}$mice during the daytime (Fig. 3A). To further characterize the interplay between Tc and Ttrunk, we combined the measurements of these two variables. As shown in Figure $3 B$, the relation was linear in both genotypes. However, the regression slope was lower in TRPM8-deficient animals $(p=$ $0.0001)$. Therefore, $\operatorname{Trpm} 8^{-/-}$mice displayed higher Ttrunk values at a given Tc, especially during the light-time.

We next measured Ttail in those mice. Previous studies have shown that tail vasomotion in rodents occurs in an on-off fashion (Young and Dawson, 1982; Hosono et al., 2001). Tail blood vessels fluctuate between constriction and dilation rather than keeping a stable moderate tonus. Large vasodilations can be observed even at an ambient temperature of $21^{\circ} \mathrm{C}$ in freely moving rodents (Hosono et al., 2001). We determined the duration and the temperatures reached in the tail vasodilatory episodes of WT and $T r p m 8^{-1-}$ mice. No significant differences were found between genotypes either in the maximum values $\left(28.1 \pm 1.6^{\circ} \mathrm{C}\right.$ vs $26.7 \pm$ $1.1^{\circ} \mathrm{C}$, light phase; $24.6 \pm 0.5^{\circ} \mathrm{C}$ vs $25.4 \pm 1.1^{\circ} \mathrm{C}$, dark phase) or in

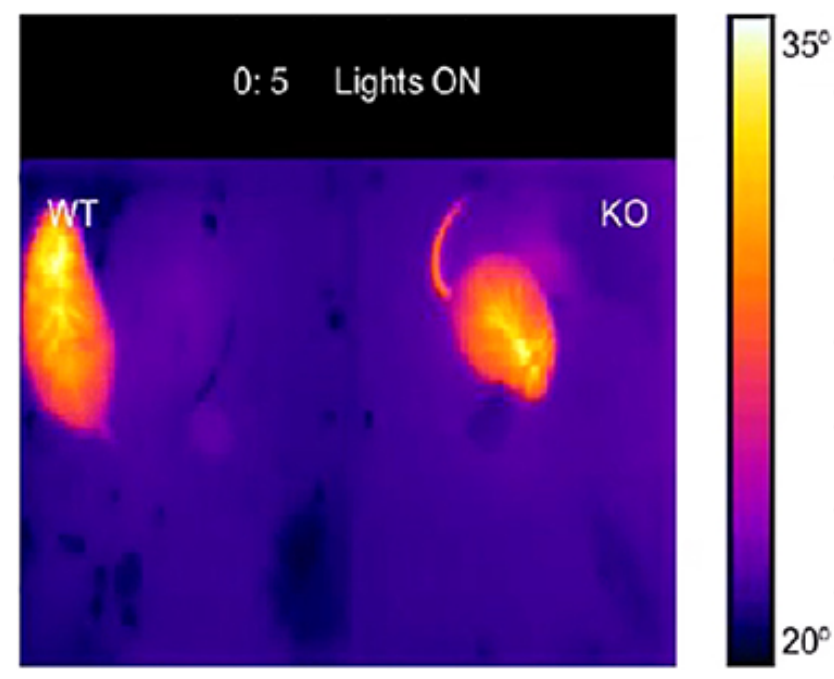

Movie 1. Trpm8-deletion increases tail vasodilation. Video recording of IR thermography of a WT (left) and a TRPM8-deficient mouse (KO, right) during $6.45 \mathrm{~h}$ of the light phase, starting at the lights-on time (0 ZT).

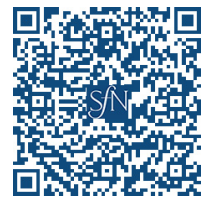

the minimum levels $\left(22.1 \pm 0.3^{\circ} \mathrm{C}\right.$ vs $22.4 \pm 0.2^{\circ} \mathrm{C}$, light phase; $21.7 \pm 0.5^{\circ} \mathrm{C}$ vs $22.1 \pm 0.5^{\circ} \mathrm{C}$, dark phase) of Ttail. However, the total time that the tail spent in a vasodilated state was greater in TRPM8-deficient mice (two-way ANOVA, genotype $p=0.043$ ), especially during the daylight period (Fig. 3C; Movie 1). This finding parallels the small diurnal drops in Tc observed in $\operatorname{Trpm} 8^{-1-}$ mice when housed at $21^{\circ} \mathrm{C}$ (Fig. 3D). 

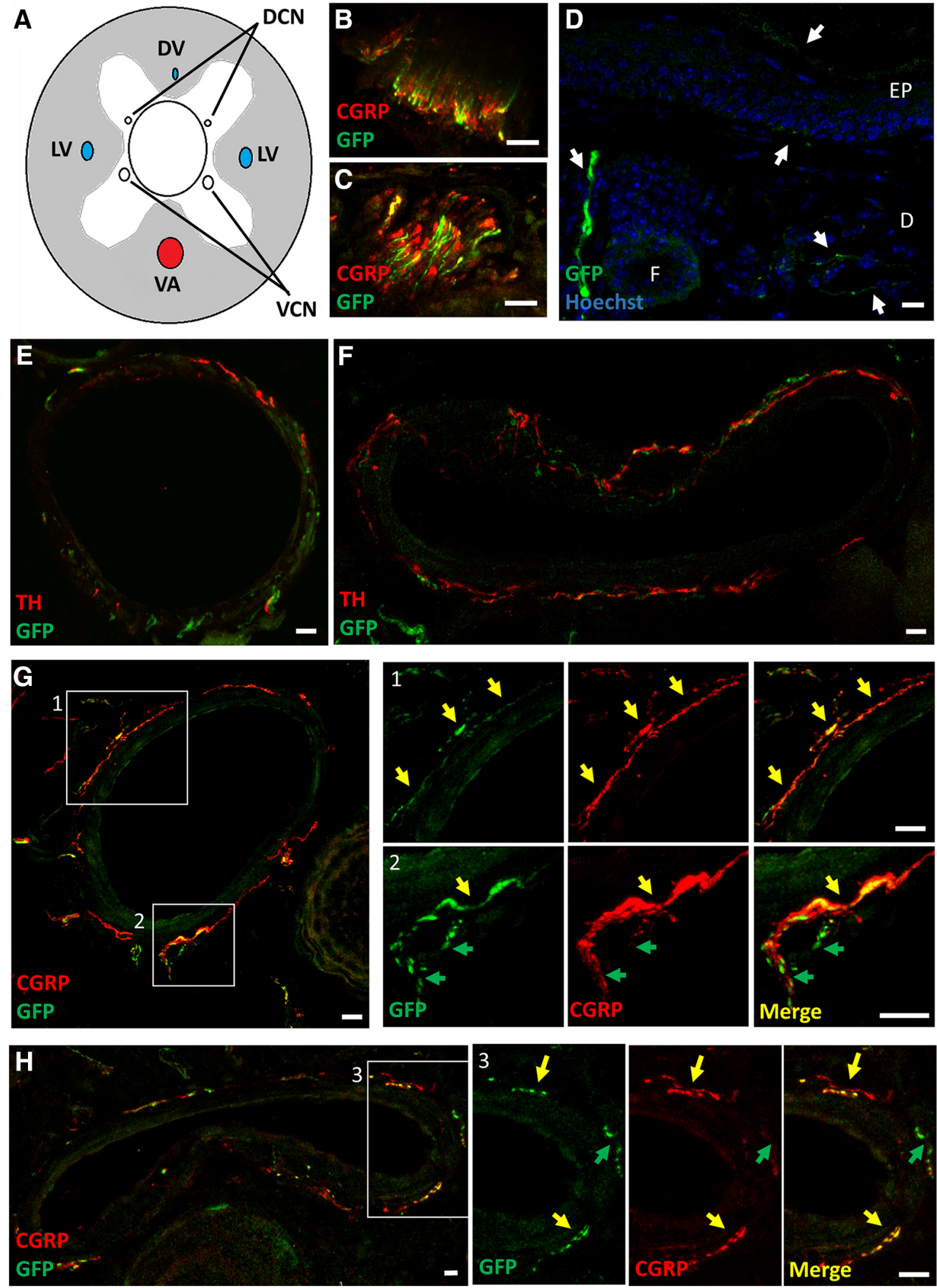

Figure 4. TRPM8-sensory fibers surround tail vessels. Representative GFP immunohistochemistry in tail sections from Trpm8-eYFP ${ }^{+}$mice. $A$, Diagram of a cross section of a mouse tail, showing the position of the ventral caudal artery (VA), lateral vein (LV), and dorsal vein (DV). The ventral and dorsal collector nerve trunks (VCN and DCN) are also shown. GFP-positive fibers traveling via the VCN $(\boldsymbol{B})$ and DCN $(\boldsymbol{C})$, together with other sensory fibers (see (GRP-positive axons). D, GFP-immunoreactive fibers in the tail skin dermis (D) and epidermis (EP), indicated by white arrows. $\boldsymbol{F}$, Skin follicle. GFP-positive fibers around the ventral caudal artery $(\boldsymbol{E}, \boldsymbol{G})$ and the lateral vein $(\boldsymbol{F}, \boldsymbol{H})$, where TH-containing fibers were also located $(\boldsymbol{E}, \boldsymbol{F})$. Amplified images corresponding to the squares 1, 2, and 3 of $\boldsymbol{G}$ and $\boldsymbol{H}$ are shown on the right. Some GFP fibers coexpress the sensory neuropeptide (GRP (yellow arrows), whereas some others do not (green arrows). Scale bar, $10 \mu \mathrm{m}$. 

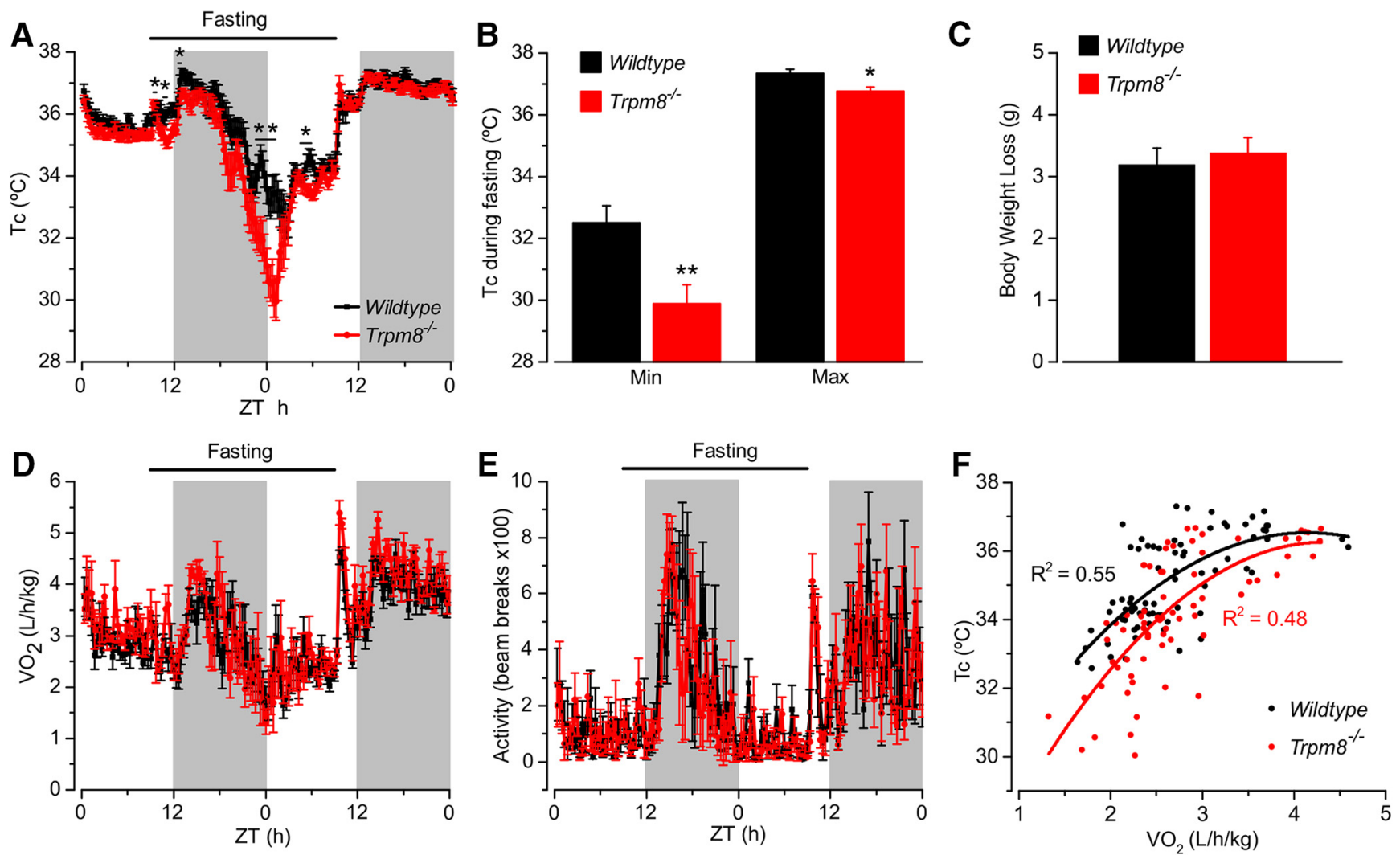

Figure 5. Food deprivation induces a deep hypothermia in $T r p m 8^{-1-}$ mice. Effect of $24 \mathrm{~h}$ fasting in WT and Trpm $8^{-1-}$ mice. Gray and white bars represent night and day, respectively. $A$, Recording of Tc calculated at 15 min intervals. (ANOVA and Bonferroni test). p values indicate significance of the post hoc test. WT, $n=14 ; \mathrm{KO}, n=15$. $\boldsymbol{B}$, Minimum and maximum Tc achieved during fasting. ${ }^{*} p=0.039,{ }^{* *} p=0.002$ (Student's $t$ test and correction FDR). WT, $n=14 ; \mathrm{KO}, n=15$. C, Body weight loss after the fasting period. $n=8$ mice/group. V0 2 (D) and spontaneous ambulatory activity $(\boldsymbol{E})$ were determined in WT and Trpm $8^{-/-}$mice using metabolic cages for $48 \mathrm{~h} . n=6$ mice/group. $\boldsymbol{F}$, Relation between $\mathrm{V}_{2}$ and Tc in WT and Trpm $8^{-/-}$mice during fasting. Each value indicates the average over $20 \mathrm{~min} . n=6$ mice/group. A polynomial quadratic regression line is shown for each genotype. All experiments were performed in male mice of 3 months of age at an ambient temperature of $21^{\circ} \mathrm{C}$. Data are mean $\pm \mathrm{SEM}$.

The measurement of $\mathrm{VO}_{2}$ and energy expenditure revealed similar levels in both groups of mice, with occasional bouts of higher $\mathrm{VO}_{2}$ in TRPM8-deficient mice (Fig. 3E). In addition, we were unable to find significant differences in BAT temperature $\left(\mathrm{T}_{\mathrm{BAT}}\right)$ determined at ZT $8-9$ by IR thermography $\left(36.5 \pm 0.6^{\circ} \mathrm{C}\right.$ vs $36.7 \pm 0.7^{\circ} \mathrm{C}, n=7$ mice/group).

To further support the hypothesis of increased heat dissipation in TRPM8-deficient mice, we determined the whole-body thermal conductance, calculated as $\mathrm{VO}_{2} /(\mathrm{Tc}-\mathrm{Ta}$ ) (Nagashima et al., 2003). Ambient temperature (Ta) was $21^{\circ} \mathrm{C}$. Thermal conductance was higher in Trpm $8^{-/-}$mice compared with WT ( $p=$ 0.00003; Fig. 3F).

These results indicate that the absence of TRPM8 activity induces an increase in heat loss, mainly by the tail, which leads to reduced Tc. Interestingly, the drop of Tc was not followed by an increase in energy expenditure, BAT activity, or by a lower Ttrunk.

TRPM8-sensory fibers surround the principal tail vessels The greater tail heat dissipation in Trpm8-KO mice might be due to a central or a peripheral effect of the lack of TRPM8. Because previous studies have reported a defective response to cold in peripheral arteries of the skin in $\operatorname{Trpm} 8^{-1-}$ mice (Pan et al., 2017), we focused our attention on the presence of TRPM8 innervation in the tail. Using a transgenic mouse line expressing YFP under the TRPM8 promoter (Morenilla-Palao et al., 2014), we demonstrated GFP-immunoreactive fibers traveling via the major collector nerve trunks (ventral and dorsal) that distribute sensory (see CGRP-positive fibers within these bundles of fibers), as well as motor and sympathetic axons (Fig. $4 A-C$ ). GFP fibers were found in the tail skin (Fig. $4 D$ ), but we also observed perivascular GFP-immunoreactive fibers (Fig. $4 E-H$ ). Indeed, GFP together with TH-positive fibers were found surrounding the ventral caudal artery, the major arterial supply to the tail. The innervation of this tail artery by the sympathetic nervous system has been previously reported (Sittiracha et al., 1987). No colocalization was seen between both types of fibers (Fig. 4E). GFP and TH immunoreactive fibers were also observed around the lateral vein (Fig. $4 F$ ), the major venous drainage of the tail. No colocalization was seen between both types of fibers (Fig. 4E,F). Some, but not all, perivascular GFP-positive fibers also coexpressed the sensory neuropeptide CGRP (Fig. 4G,H). This indicates the existence of two different populations of TRPM8-sensory fibers in the tail: one with and the other without CGRP.

All these findings underline a relevant role of TRPM8 in the regulation of tail vasomotor tone.

\section{Trpm8-KO mice display a deep hypothermia during caloric} restriction due to tail vasodilation

Considering that, in the absence of TRPM8 other thermal sensors can activate core-dependent mechanisms that drive thermoregulatory responses to cooling, which might blur the actual function of this channel on the maintenance of Tc, we looked for a physiological situation in which the hypothalamus does not elicit 

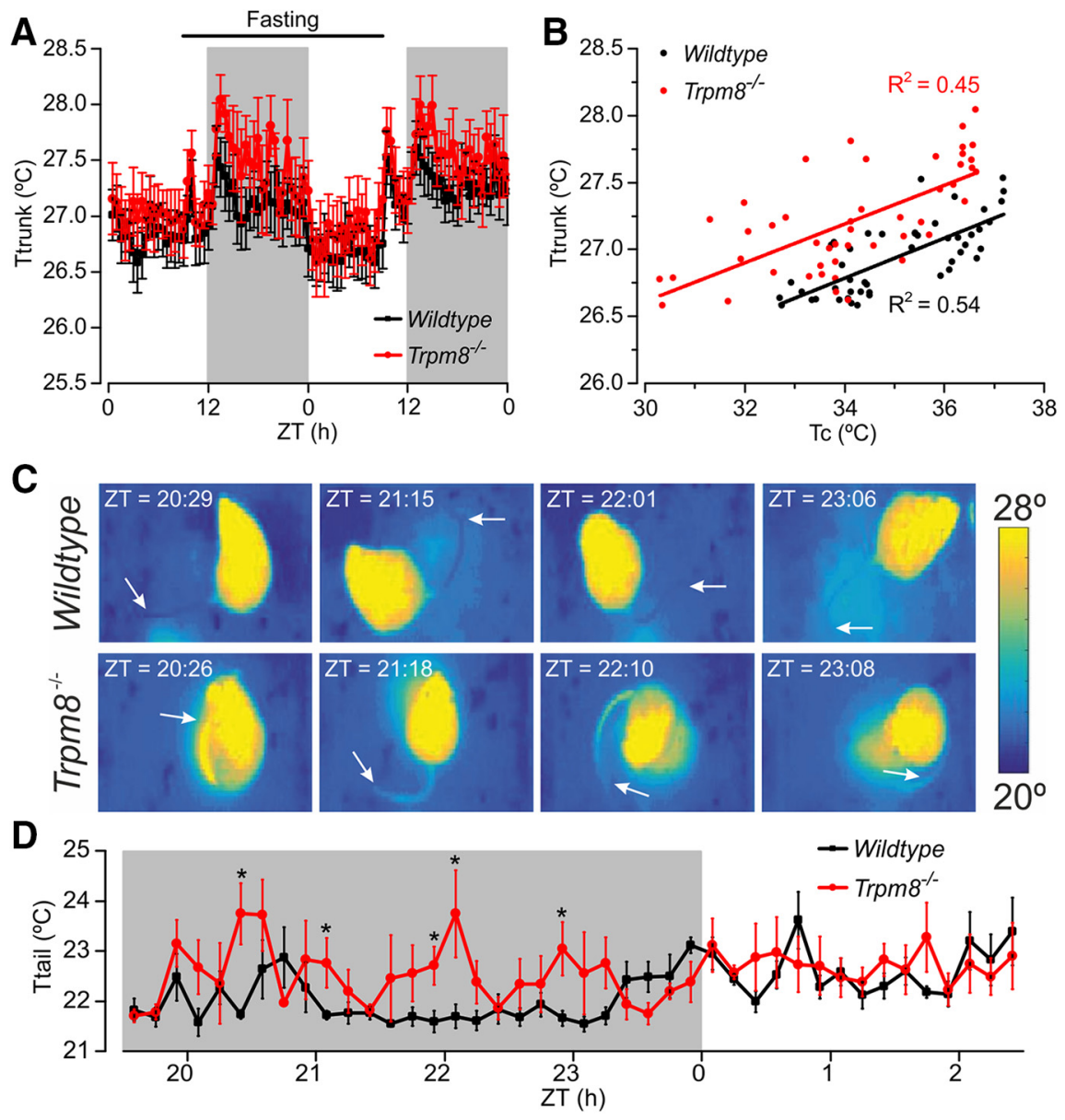

Figure 6. Food deprivation increased tail heat dissipation in $\operatorname{Trpm} 8^{-/-}$mice. Mice were maintained in fasting for $24 \mathrm{~h}$ at $21^{\circ} \mathrm{C}$. $A$, Ttrunk determined by IR thermography. Values indicate the average of the maximum levels of the Ttrunk in 10 min intervals. $\boldsymbol{B}$, Relation between Tc and Ttrunk in WT and Trpm $8^{-/-}$mice during fasting. Each point represents the average over $20 \mathrm{~min} . n=$ 4 WT and $3 \mathrm{KO}$ mice. A linear regression line is shown for each genotype. $C$, Representative images of IR thermography of fasting WT and Trpm $8^{-/-}$mice at different ZT hours in the interval from ZT 19.5 to ZT 0. Arrows point to mice's tail tips. D, Ttail as determined by IR thermography and recorded from ZT 19.5 to ZT 2.5. Values indicate the average of the maximum levels of the Ttail in $10 \mathrm{~min}$ intervals. ${ }^{*} p<0.05(p=0.046, p=0.0055, p=0.013, p=0.018, p=0.0095)$, Fisher's exact permutation test. Experiments were performed in male mice of 7 months of age. $n=4$ WT and $3 \mathrm{KO}$ mice. Data are mean \pm SEM.

those responses. Caloric deprivation is one of these conditions. During fasting, Tc in rodents suffers a rapid and regulated decrease, associated with a reduction in metabolic rate, as part of the adaptive response to energy deprivation (Landsberg, 2012). In this physiological setting, the hypothalamus does not drive thermal defense responses probably reflecting that the central "setpoint/s" can be regulated in the interest of energy conservation (Nagashima et al., 2003; Landsberg, 2012). Taking into account these premises, we determined Tc in Trpm $8^{-/-}$and control littermates during $24 \mathrm{~h}$ of food deprivation at an environmental temperature of $21^{\circ} \mathrm{C}$. Compared with WT animals, Trpm $8^{-/-}$ mice exhibited a much deeper reduction in Tc during fasting. The hypothermia was observed, especially in the hours at the end of the dark phase and immediately after the lights onset (Fig. $5 \mathrm{~A}$ ), with a nadir below $30^{\circ} \mathrm{C}, \sim 2.5^{\circ} \mathrm{C}$ lower than control animals $(p<$ 0.01 ) (Fig. $5 A, B$ ).

Next, we evaluated possible factors inducing this large drop of Tc in $\operatorname{Trpm} 8^{-/-}$mice during food deprivation. Body weight change (Fig. 5C) and $\mathrm{VO}_{2}$ levels (Fig. 5D) displayed a similar reduction in both genotypes. Likewise, motor activity exhibited a comparable pattern of changes in the two experimental groups (Fig. 5E). The graphical representation of the relation between
$\mathrm{VO}_{2}$ and $\mathrm{Tc}$ measurements during the fasting period showed that a decrease in $\mathrm{VO}_{2}$ was associated with a reduction in $\mathrm{Tc}$ in both experimental groups (Fig. $5 F$ ). Nevertheless, as $\mathrm{VO}_{2}$ decreased with fasting, Tc values for any given $\mathrm{VO}_{2}$ were progressively lower in $\operatorname{Trpm} 8^{-/-}$mice compared with WT. This suggests that the larger drop of Tc in TRPM8-deficient mice might be due to greater heat loss. To demonstrate an increased heat dissipation, we measured Ttrunk and Ttail. Ttrunk exhibited a decrease during fasting, as it has been previously shown in the rat by other authors (Nagashima et al., 2003). No significant differences were found in Ttrunk between both genotypes of mice (Fig. 6A). However, representing the relationship between Tc and Ttrunk revealed higher levels of Ttrunk at a given Tc in $\operatorname{Trpm} 8^{-/-}$mice. In the absence of TRPM8, the regression line was shifted up on the $y$ axis, but with a similar slope to the fit line of WT mice (Fig. $6 B$ ).

We finally determined Ttail during the interval of maximum hypothermia (from ZT 19.5 to ZT 2.5). As already reported by other authors in rats (Nagashima et al., 2003), WT mice exhibited very low levels of Ttail during the dark hours of fasting, with almost no episodes of vasodilations (Fig. 6C,D). In contrast, Ttail of TRPM8deficient mice still displayed peaks of higher temperature (Fig. 6C,D), which paralleled the fall of Tc observed in this time schedule. After the lights were turned on, both groups of animals displayed a similar increase in Ttail.

Collectively, our results reinforce the relevant role of TRPM8-mediated information in the regulation of heat dissipation and tail vasomotor control. Furthermore, our findings suggest that the activation of thermogenic and heat-conserving (i.e., back skin vasoconstriction) mechanisms during fasting occur at lower Tcs in $\operatorname{Trpm} 8^{-/-}$mice compared with WT mice.

\section{Lack of $\operatorname{Trpm} 8$ induces the development of adult-onset obesity at mild cold temperatures}

As $\operatorname{Trpm} 8^{-/-}$mice were significantly hyperphagic in relation to WT counterparts when housed at $21^{\circ} \mathrm{C}$ (Fig. $2 F$ ), we examined in more detail the effects of different environmental temperatures on the diurnal and nocturnal food consumption in male mice. As shown in Figure 7, the night-time cumulative eating for $7 \mathrm{~d}$ was similar regardless of genotype at any of the ambient temperatures evaluated $\left(17^{\circ} \mathrm{C}, 21^{\circ} \mathrm{C}, 25^{\circ} \mathrm{C}\right.$, and $\left.29^{\circ} \mathrm{C}\right)$. In contrast, we observed notable differences in daytime food intake. Thus, $\operatorname{Tr} p m 8^{-1-}$ mice showed higher daylight intake when housed at $21^{\circ} \mathrm{C}$ and a small increment at $25^{\circ} \mathrm{C}$, but similar light-phase food consumption at thermoneutrality $\left(29^{\circ} \mathrm{C}\right)$ or at colder temperatures $\left(17^{\circ} \mathrm{C}\right)$. Therefore, TRPM8 deficiency induces a significant increase in daytime food consumption, but only when mice were exposed to a range of mild cold temperatures, those most significant for TRPM8 physiological activity (Bautista et al., 2007). 


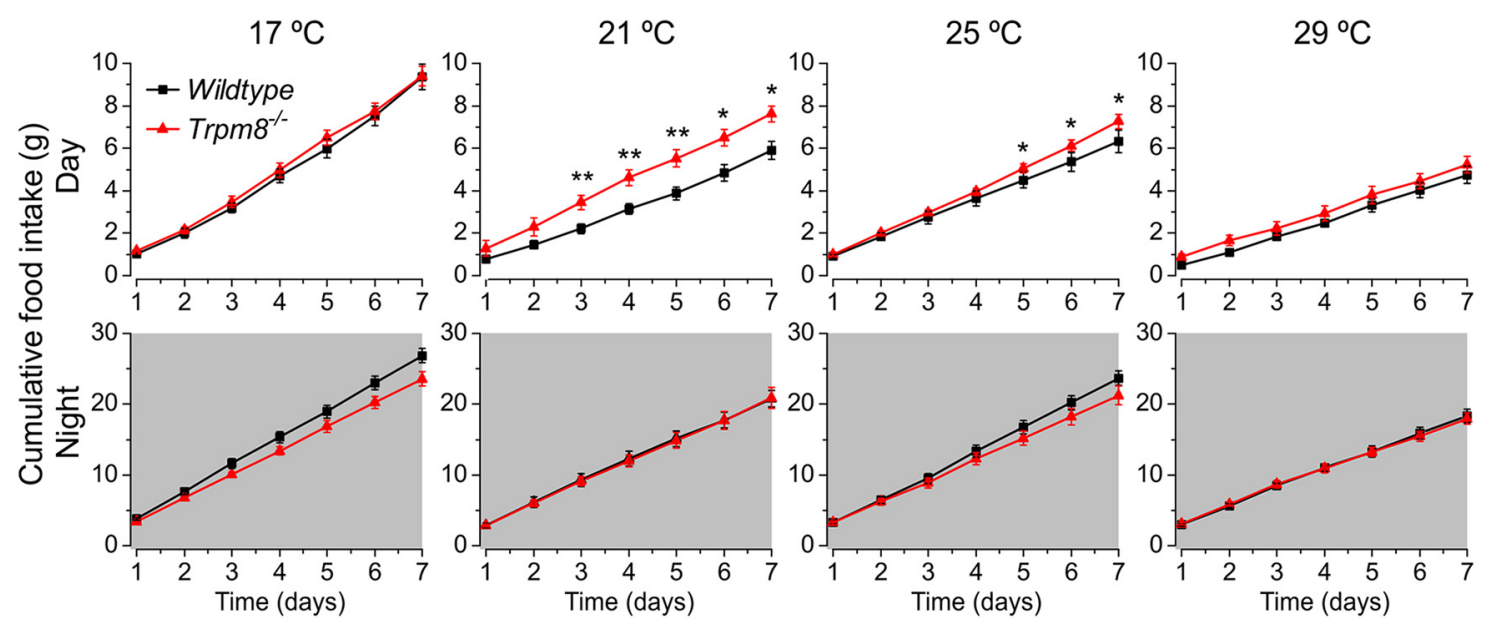

Figure 7. TRPM8 deficiency causes daytime hyperphagia in a temperature-dependent way. Effect of different ambient temperatures $\left(17^{\circ} \mathrm{C}, 21^{\circ} \mathrm{C}, 25^{\circ} \mathrm{C}\right.$, and $\left.29^{\circ} \mathrm{C}\right)$ on daytime and night-time food intake. Results were plotted as cumulative food intake for $7 \mathrm{~d}$ in mice at the temperatures indicated. ${ }^{*} p<0.05$; ${ }^{* *} p<0.01\left(21^{\circ} \mathrm{C}\right.$ daylight: $p=0.0087, p=0.0058, p=0.0071, p=0.012$, and $p=0.011 ; 25^{\circ} \mathrm{C}$ daylight: $p=0.02, p=0.017, p=0.023$ ) (Student's $t$ test). Mice were males of 6 months of age. WT, $n=5 ; \mathrm{K} 0, n=4$. Data are mean \pm SEM.

The diurnal hyperphagia observed in Trpm8-KO mice led us to evaluate the possible role of this cold thermoreceptor in longterm body weight and energy homeostasis, as common obesity is often the consequence of minor energy imbalances accumulated over a prolonged period of time (World Health Organization, 2000). Thus, we followed the body weight of male and female WT and $\operatorname{Trpm} 8^{-1-}$ mice consuming a standard diet. To discriminate possible temperature-dependent effects we raised these animals at two different environmental temperatures: $21^{\circ} \mathrm{C}$ and $24^{\circ} \mathrm{C}$ $25^{\circ} \mathrm{C}$. Compared with WT, Trpm 8 -KO mice housed at $21^{\circ} \mathrm{C}$ exhibited a progressive greater increase in body weight. The effect was slow, becoming significant only after 7 months of age and observed in both sexes (Fig. 8A). The greater body mass was due to higher levels of body fat, as determined by magnetic resonance spectroscopy. No differences were observed in lean mass (Fig. $8 B$ ). Moreover, obese male TRPM8-deficient mice of 8 months of age also displayed a significant fasting hyperglucemia and showed a prolonged hyperglucemia in response to intraperitoneal glucose administration (ipGTT) (Fig. 8C). Other metabolic parameters associated with fat and glucose homeostasis were also affected. Thus, higher serum levels of leptin (45.2 \pm 6.5 vs $10.2 \pm$ $3.6 \mathrm{ng} / \mathrm{ml}, n=5, p<0.05)$ and insulin $(2.4 \pm 0.1$ vs $0.6 \pm 0.1$ $\mathrm{ng} / \mathrm{ml}, n=5, p<0.05$ ) were found in 12-month-old $\operatorname{Tr} p m 8$-KO animals compared with control mice.

The diurnal hyperphagia appeared at an early age. Mice as young as 2-3 months old, both male and female, present higher levels of food intake during the daytime (Fig. $8 D, G$ ), accompanied by greater values of respiratory quotient levels $\left(\mathrm{RQ}, \mathrm{VCO}_{2} /\right.$ $\mathrm{VO}_{2}$ ), especially during daylight (Fig. $8 E, H$ ). As RQ is an indicator of substrate preference (carbohydrates vs fat), our results show that young preobese Trpm 8 -KO mice display a shift in energy substrate utilization with reduced fat oxidation during the lights on period, which probably favors fat deposition. Interestingly, no significant changes were observed in energy expenditure between genotypes (Fig. $8 F, I$ ).

Next, we asked whether a higher housing temperature affected the development of obesity in Trpm $8^{-/-}$mice. We therefore monitored the body mass evolution of mice housed at $24^{\circ} \mathrm{C}-25^{\circ} \mathrm{C}$. At this ambient temperature, the diurnal food intake in deficient males was only slightly higher than in control mice (Fig. 7). Body weight of male mice raised at this higher housing temperature was comparable in both genotypes (Fig. $9 A$ ), with similar weights in the different fat depots (data not shown). Of note, Trpm $8^{-/-}$ female mice grown at $24^{\circ} \mathrm{C}-25^{\circ} \mathrm{C}$ still developed obesity, although it started later in life (12 months of age), compared with the phenotype observed at $21^{\circ} \mathrm{C}$ (Fig. 9A). Indeed, 14-month-old female Trpm8-deficient mice presented a marked increase in adiposity (Fig. 9B,C), with a great enlargement in subcutaneous and gonadal white fat and a liver showing a higher content of lipid droplets (Fig. 9B-E). The increase in fat mass was accompanied by hyperleptinemia, hyperinsulinemia, fasting hyperglucemia, reduced glucose tolerance (ipGTT), and hypercholesterolemia (Fig. $9 F-I$ ), revealing that, at this higher housing temperature, the absence of TRPM8 still induced obesity in the old female mice associated with metabolic alterations.

In summary, we show that the lack of TRPM8 leads to lateonset obesity in mice accompanied by glucose and lipid metabolic dysfunction. A persistent diurnal hyperphagia and lower fat oxidation constitute plausible underlying mechanisms for this phenotype in the background of a deficient thermoregulatory adjustment to mild cold temperatures due, at least in part, to an impaired tail vasomotor regulation.

\section{Discussion}

Survival of animals in the wild depends on their ability to maintain Tc in the face of rapid and intense fluctuations in their thermal environment. The coupling of energy homeostasis to thermoregulation is essential in this process, including the effect of cold exposure on food intake, thermogenesis, and heatconserving mechanisms (Cannon and Nedergaard, 2009). Here, we demonstrate that the ion channel TRPM8 is required for a precise thermoregulatory response to cold and fasting and unveil an important role of TRPM8 in transducing peripheral thermal information to adjust energy homeostasis to thermoregulation when living in mild cold temperatures.

Many previous studies have reported the key role of TRPM8 in sensing cold temperatures by a subset of cold thermoreceptors innervating the skin (for review, see Almaraz et al., 2014). Other studies have established that TRPM8 also plays a significant role in thermoregulatory responses to cold (Bautista et al., 2007; Colburn et al., 2007; Dhaka et al., 2007; Tajino et al., 2007, 2011; Almeida et al., 2012; Gavva et al., 2012). Nevertheless, the existing data and our findings show that mice lacking TRPM8 present only a moderate impairment in their ability to maintain core 

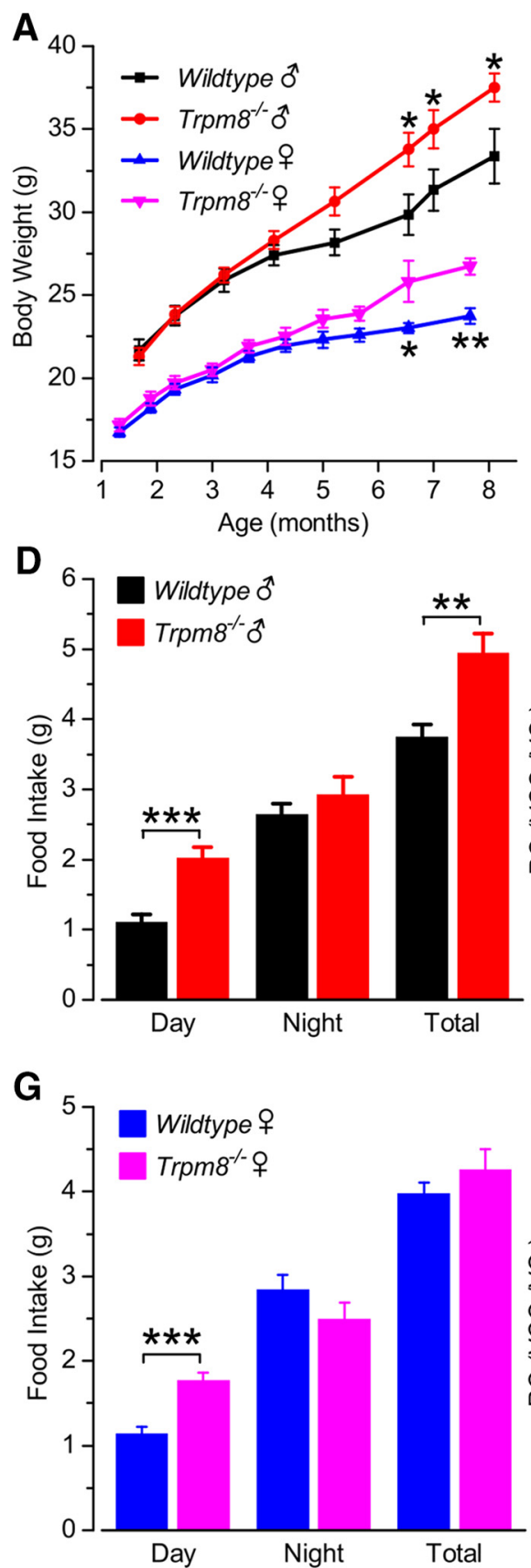
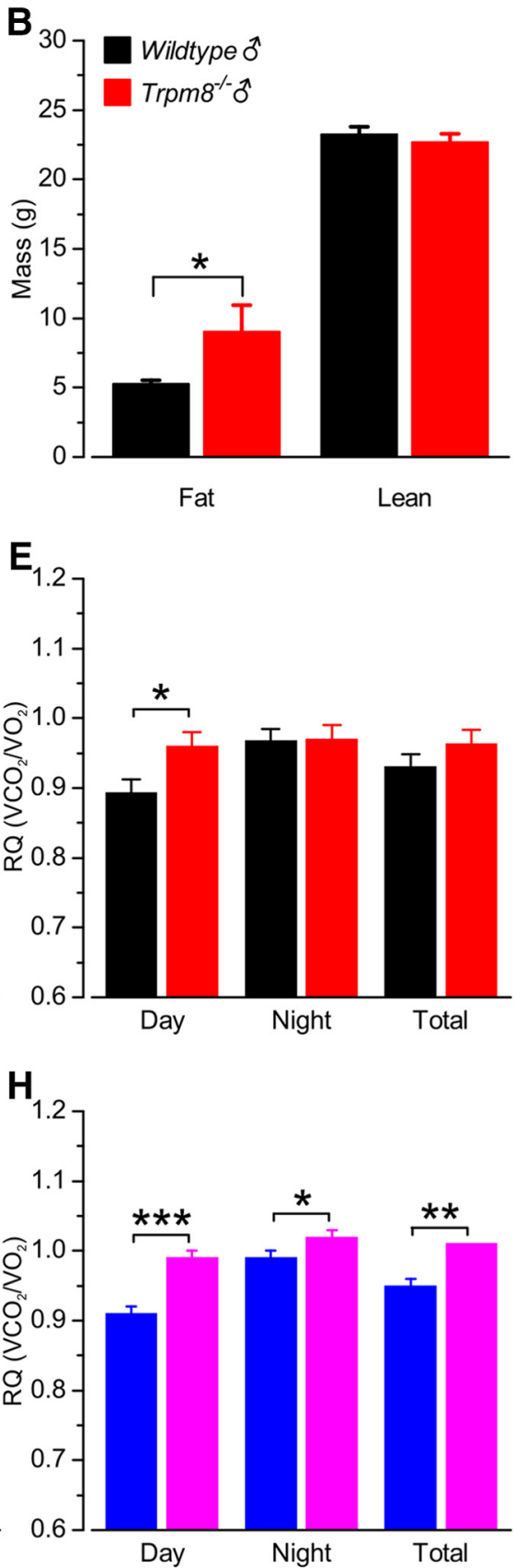

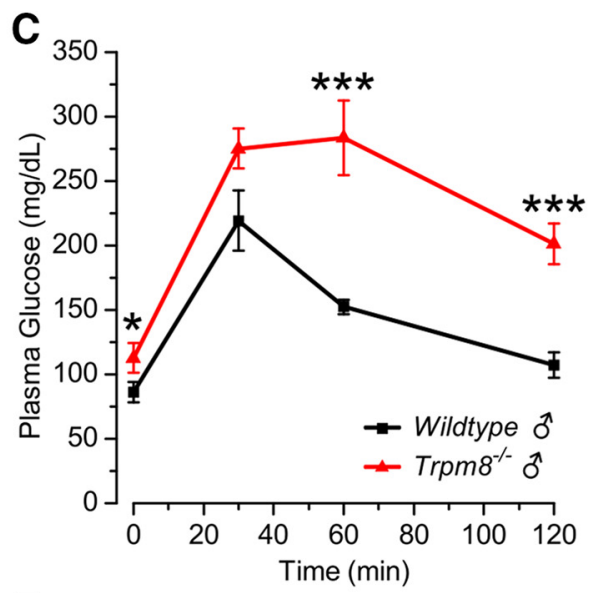

F
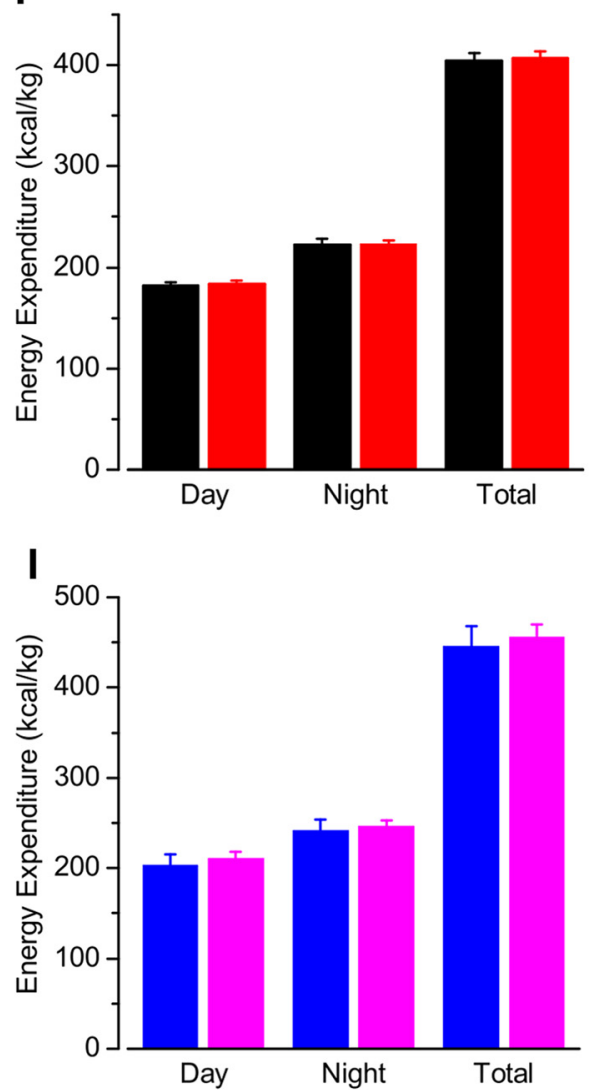

Figure 8. Male and female Trpm $8^{-1-}$ mice develop obesity when housed at $21^{\circ} \mathrm{C}$. $A$, Body weight curves of WT and $\operatorname{Trpm} 8$-deficient male and female mice housed at $21^{\circ} \mathrm{C}$ with a standard diet. Males: WT, $n=16 ; \mathrm{K} 0, n=16$; females: WT, $n=16 ; \mathrm{K} 0, n=16 .{ }^{*} p<0.05\left(p=0.03, p=0.044\right.$, and $p=0.025$ in males; $p=0.033$ in females) ${ }^{* *} p<0.01$ ( $p=0.0012$ ). Fisher's exact permutation test. $\boldsymbol{B}$, Body fat and lean mass of male mice (8-month-old) determined by magnetic resonance spectroscopy. $n=6$ WT and $5 \mathrm{KO}$ mice. ${ }^{*} p=0.037$ (Student's $t$ test). $\boldsymbol{C}$, Serum glucose levels before and 30,60, and 120 min after an ipGTT in 5 WT and 4 KO male mice ( 8 months of age). ${ }^{*} p=0.04,{ }^{* * *} p<0.001(p=0.00065$ and $p=0.0005)$. (Student's $t$ test). Food intake $(\boldsymbol{D}, \boldsymbol{G})$, $\mathrm{RQ}(\boldsymbol{E}, \boldsymbol{H})$, and energy expenditure $(\boldsymbol{F}, \boldsymbol{I})$ in male $(\boldsymbol{D}-\boldsymbol{F})$ and female $(\boldsymbol{G}-\boldsymbol{I})$ mice of $2-3$ months of age were determined in metabolic cages for $48 \mathrm{~h} . n=4-6$ mice $/$ group. ${ }^{*} p<0.05,{ }^{* *} p<0.01$, ${ }^{* * *} p<0.001$ (two-way ANOVA and post hoc Bonferroni test). $p$ values indicate significance of the post hoc test. Males, $\mathrm{Fl}, p=0.00043$ and $p=0.0016 ; \mathrm{RQ}, p=0.033 ; \mathrm{females}$ : $\mathrm{Fl}, p=0.0008$; $\mathrm{RQ}, p=0.0005, p=0.04$, and $p=0.0011$. Data are mean \pm SEM.

temperature during cold exposure, with a maximum reduction in Tc of $\sim 0.7^{\circ} \mathrm{C}$. The magnitude of this effect seems smaller than would be hypothesized if TRPM8 was the only sensor during cold thermoregulation. The largely consistent results observed by other authors with pharmacological inhibition (Knowlton et al., 2011; Tajino et al., 2011; Almeida et al., 2012; Gavva et al., 2012; Feketa et al., 2013), as well as our new results with the $\operatorname{Trpm} 8 D \mathrm{TR}^{+}$mice in which we acutely ablated the TRPM8-expressing neurons support a modest effect. Similarly, ablation of TRPV1-lineage neurons, which include all TRPM8-containing neurons, led to moderate defects in thermoregulation to cold environments, despite the lack of acute responses to noxious cold in these mice (Mishra et al., 2011).

One possible explanation is that TRPM8 might not be the only cold sensing system in the periphery, as it has been recently reported (Winter et al., 2017), although the profound decrease in cold sensitivity is a well-established consequence of $\operatorname{Trpm} 8$ deletion. However, the thermoregulatory system is highly redundant 


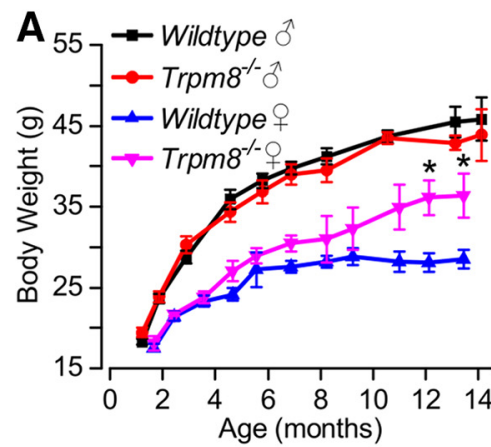

D

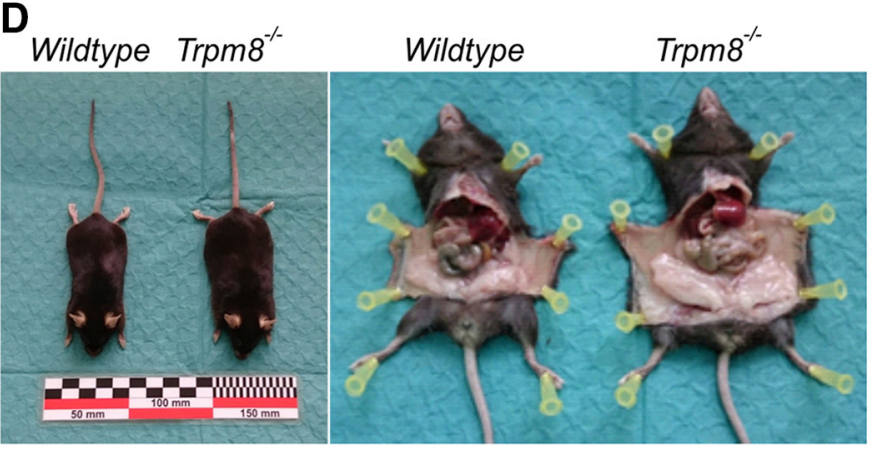

B

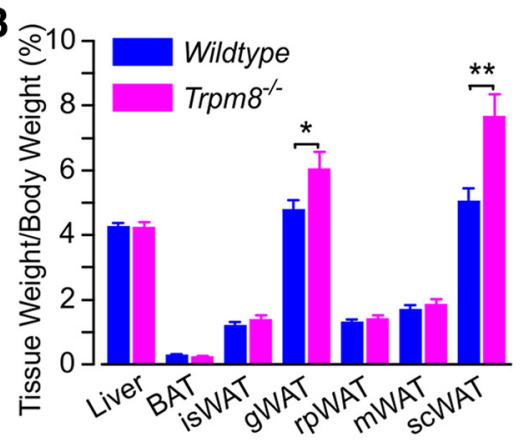

E

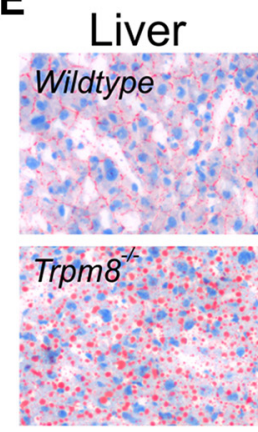

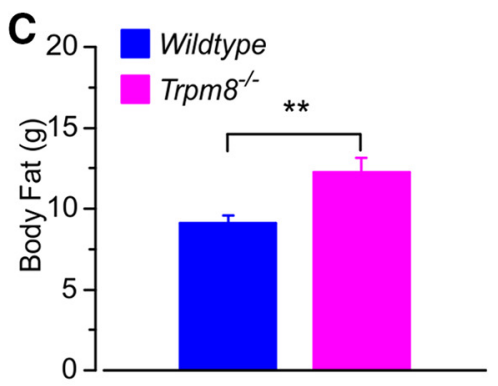

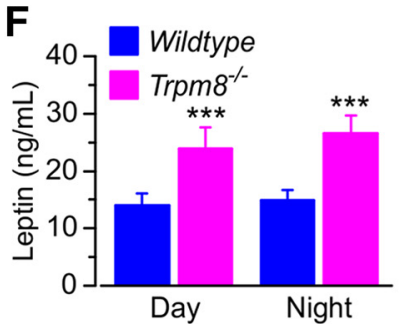

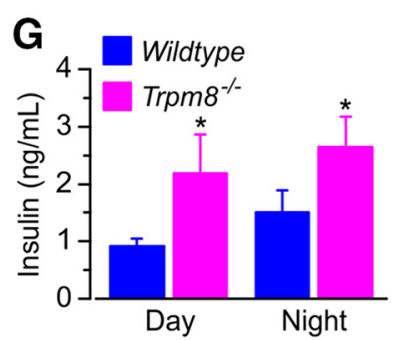

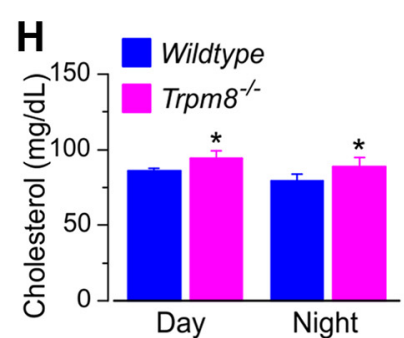

scWAT
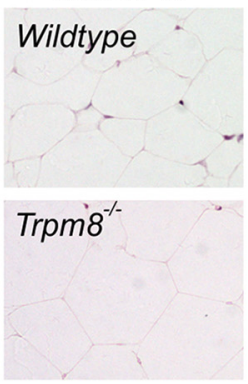
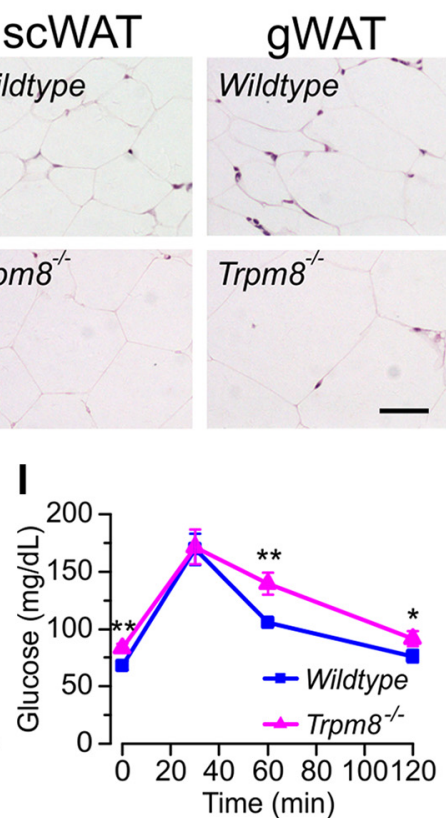

Figure 9. Late-onset obesity in Trpm $8^{-/-}$aged female mice housed at $24^{\circ} \mathrm{C}-25^{\circ} \mathrm{C}$. $\mathrm{A}$, Body weight curves of WT and TRPM 8 -deficient male and female mice housed at $24^{\circ} \mathrm{C}-25^{\circ} \mathrm{C}$ with a standard diet. Males: WT, $n=23 ; \mathrm{KO}, n=23$; females: WT, $n=22 ; \mathrm{K} 0, n=23 .{ }^{*} p<0.05$ ( $p=0.028$ and $p=0.04$ ). Fisher's exact permutation test. $\boldsymbol{B}$, Weight of liver, BAT, and fat depots (subcutaneous [sc], gonadal [g], interscapular [is], retroperitoneal [rp], mesenteric [m] WAT) expressed in relation to body weight of female mice of 14 months of age. $n=21$ WT and $22 \mathrm{KO}$ mice. ${ }^{*} p=0.04,{ }^{* *} p=$ 0.002 (Student's $t$ test). C, Total fat mass determined by magnetic resonance in 14-month-old female mice. $n=22$ WT and 23 K0 mice. ${ }^{* *} p=0.0035$ (Student's $t$ test). $\boldsymbol{D}$, Representative photographs of 14-month-old female mice of both genotypes of mice with their abdominal fat depots exposed. $\boldsymbol{E}$, Microphotographs of liver, subcutaneous (sc) and gonadal ( $\mathrm{g}$ ) WAT stained with hematoxylin and eosin (WATs) and oil red (liver) from 14-month-old female mice. Scale bar, $50 \mu \mathrm{m}$. $\boldsymbol{F}$, Serum leptin $(\boldsymbol{F})$, insulin $(\boldsymbol{G})$, and cholesterol $(\boldsymbol{H})$ levels were determined at 12 a.m. and 12 p.m. $n=8-10$ mice/group. ${ }^{*} p<0.05,{ }^{* * *} p<0.001$ (two-way ANOVA). The factor "genotype" was statistically significant $(p=0.0002, p=0.0163, p=0.049$, respectively). $I$, Serum glucose levels before and 30,60, and 120 min after ipGTT. $n=6$ mice/group. ${ }^{*} p=0.04,{ }^{* *} p=0.004$ (Student's $t$ test). Data are mean \pm SEM.

and functions by integrating deep and peripheral temperature signals (Romanovsky, 2014). Therefore, the system might function in the absence of a TRPM8-induced cold signal from the skin. Indeed, our results show that TRPM8-deficient mice present a functional BAT, an almost comparable increase in motor activity upon cooling and a retained capability of hyperphagia in response to cold. This, together with the results of Feketa et al. (2013) reporting that $\operatorname{Trpm} 8^{-/-}$mice displayed similar coldinduced shivering and tachycardia, indicates that TRPM8independent mechanisms are capable of regulating all these heat-generating thermoregulatory effectors, although the adjustment of Tc is less precise. Eventually, as we will discuss in more detail below, a new steady state seems to be established, wherein Tc is still defended but at a lower than normal level.

Indeed, we found a greater heat dissipation in TRPM8-deficient mice, mainly due to increased tail vasodilation. During mild cold exposure $\left(21^{\circ} \mathrm{C}\right)$, longer vasodilation episodes in $\operatorname{Trpm} 8^{-/-}$ mice paralleled the falls of Tc observed in the light phase of these animals. Previous data from Almeida et al. (2012) showing a small delay in tail vasoconstriction in rats treated with an antagonist of TRPM8 and transferred to $21^{\circ} \mathrm{C}$ also pointed to a putative role of this ion channel in tail vasomotor control in rodents.

Thermoregulatory alterations of TRPM8-deficient mice were more evident during fasting. In this situation, in which the hypothalamus does not mount defense responses to avoid the drop of temperature, $\operatorname{Trp} m 8^{-/-}$mice exhibited a torpor-like drop in Tc, reaching values below $30^{\circ} \mathrm{C}$, with an increased heat loss by higher levels of tail vasodilation. Therefore, all our data indicate that TRPM8 signaling is required to achieve a fine adjustment in tail vasoconstriction in mice during both fed and fasting conditions. In our hands, no mRNA of TRPM8 was found in the ventral caudal artery of the tail, as determined by RT-PCR (data not shown). In contrast, we demonstrated the presence of TRPM8- expressing sensory fibers innervating not only the tail skin, but also surrounding the main tail vasculature (i.e., ventral caudal artery and the lateral vein). This finding reinforces a role of TRPM8-sensory afferent information from the skin surface, but also from the tail perivascular area, in tail vasomotor regulation. 
In addition, our findings suggest that TRPM8 activity is also required to set accurate Tc thresholds for the activation of warming mechanisms. Certainly, Tc was allowed to decrease more in TRPM8-deficient mice before heat retaining (i.e., skin vasoconstriction) and thermogenic mechanisms were activated, suggesting a downward shift of Tc thresholds for warming mechanisms. The phenotype was more clearly evidenced in the fasting model.

While the apparent deficits in thermoregulation due to TRPM8 deficiency were mild, they still led to profound long-term effects in energy homeostasis in defined environmental contexts (i.e., mild cold temperatures). The process was subtle but persistent, probably reflecting compensatory responses to thermoregulatory needs. Indeed, when housed at $21^{\circ} \mathrm{C}$, an ambient temperature at which TRPM8 activity is most physiologically relevant (Bautista et al., 2007), $\operatorname{Trpm} 8^{-/-}$mice, both males and females, developed late-onset obesity with an altered glucose and lipid metabolism. A small but constant daylight hyperphagia together with higher levels of RQ, especially during the day, probably constitute causal factors in the development of the obese phenotype. The increase in RQ likely follows the hyperphagia, as suggested by others (Abreu-Vieira et al., 2015) and is a good predictor for obesity in humans (Zurlo et al., 1990; Seidell et al., 1992; Galgani and Ravussin, 2008). Furthermore, factors, such as circadian timing of energy intake and fuel utilization (carbohydrates vs fat), strongly influence weight gain (Galgani and Ravussin, 2008; Arble et al., 2009; Gluck et al., 2011; Hibi et al., 2013). Collectively, our results indicate that the absence of active TRPM8 channels induces an increased ingestive behavior coupled with reduced fat utilization during the lights-on phase, a period normally dominated by rapid eye movement sleep in rodents, which implies oxidative sparing of triglycerides and increased fat deposition (Zurlo et al., 1990; Seidell et al., 1992), which promotes the appearance of an obese phenotype and metabolic alterations in the long-term.

When an individual is exposed to cold, a coordinated increase in thermogenesis and food intake is required. In lean chow-fed mice, the energy that is necessary to sustain a thermogenic program to maintain Tc in the cold comes mainly from feeding, and not so much fueled by oxidation of fat reserves or lean mass. This protects body composition (Jaroslawska et al., 2015). The neural central circuitry regulating cold-induced food intake is still not understood and the factors that establish the levels of eating in relation to different ambient temperatures are also under discussion. Previous data suggest that food intake is not necessarily determined by total energy expenditure, nor by the animal's body temperature, but it might be set by the requirements for heat production (Brobeck, 1997; Jaroslawska et al., 2015). According to Brobeck (1997), the amount of food taken at any one time would depend upon how much extra heat is produced from food, and how rapidly the extra heat is lost from the body. Therefore, food intake would be determined, at least partly, by the organism's ability to dissipate heat. Whether TRPM8-deficient mice display daytime hyperphagia when housed at mild cold temperatures due to their increased tail heat dissipation and/or their decreased Tc is still an open question. Alternatively, TRPM8sensory afferent information might be required directly for an optimal regulation of hypothalamic neuronal cells responsible for eating behavior in the cold. Ongoing studies of our group will help clarify these issues.

The daytime hyperphagia induced by TRPM8 deficiency was critically dependent on ambient temperature. It was most significant in animals housed at $21^{\circ} \mathrm{C}$. Consequently, when mice were housed at $24^{\circ} \mathrm{C}-25^{\circ} \mathrm{C}$ (lower level of activation of TRPM8), we did not find differences in body weight between both genotypes of males. Trpm $8^{-/-}$females, though, still displayed greater body fat and glucose and lipid metabolic alterations at this higher environmental temperature but starting at a more advanced age. This gender-dependent difference is probably due to sex differences in thermoregulation. Indeed, females present a higher surface area to volume ratio and the TNZ interval starts at higher ambient temperatures (Anderson et al., 1995).

Our results seem to contradict previous studies by other authors, who did not find changes in the body mass in TRPM8deficient mice compared with controls (Ma et al., 2012) or even described a lower body weight (McCoy et al., 2013). These differences might be explained by several factors: (1) their shorter follow-up times: 16 weeks (McCoy et al., 2013) or until 28 weeks of age (Ma et al., 2012). As indicated, obesity started to manifest after 30 weeks; and (2) their smaller number of animals evaluated: 4-6 animals per genotype. We have studied a minimum of 16 mice per genotype and sex, with a certain grade of variability in body weight in individual mice. In our hands, obesity in aged mice was accompanied by hyperglycemia, hyperinsulinemia and prolonged response to glucose challenge.

In conclusion, TRPM8 is required for an accurate thermoregulatory response to cold and fasting, playing a key role in the regulation of tail vasomotor tone. Overall, our results highlight an important and novel role of TRPM8 coupling mild cold ambient sensing and thermoregulation to an optimal ingestive thermoregulatoy response. Notwithstanding the differences in thermoregulation between mice and humans, peripheral cold thermoreceptors are very similar in both species and mild temperatures are commonly experienced by humans, which underscores the potential involvement of this ion channel in human health. Thus, sustained alterations in TRPM8 function (e.g., polymorphisms) may represent a hitherto unrecognized contributing factor in the pathophysiology of obesity. Finally, a better understanding of the mechanisms coupling thermosensation and thermoregulation to energy homeostasis, including TRPM8 function, may lead to a better knowledge of the pathogenesis of obesity and its metabolic consequences in humans and the development of new strategies for the prevention and treatment of this complex, serious, and epidemic disease.

\section{References}

Abreu-Vieira G, Xiao C, Gavrilova O, Reitman ML (2015) Integration of body temperature into the analysis of energy expenditure in the mouse. Mol Metab 4:461-470. CrossRef Medline

Almaraz L, Manenschijn JA, de la Peña E, Viana F (2014) TRPM8. Handb. Exp Pharmacol 222:547-579. CrossRef Medline

Almeida MC, Hew-Butler T, Soriano RN, Rao S, Wang W, Wang J, Tamayo N, Oliveira DL, Nucci TB, Aryal P, Garami A, Bautista D, Gavva NR, Romanovsky AA (2012) Pharmacological blockade of the cold receptor TRPM8 attenuates autonomic and behavioral cold defenses and decreases deep body temperature. J Neurosci 32:2086-2099. CrossRef Medline

Anderson GS, Ward R, Mekjavić IB (1995) Gender differences in physiological reactions to thermal stress. Eur J Appl Physiol Occup Physiol 71:95101. CrossRef Medline

Arble DM, Bass J, Laposky AD, Vitaterna MH, Turek FW (2009) Circadian timing of food intake contributes to weight gain. Obesity 17:2100-2102. CrossRef Medline

Bautista DM, Siemens J, Glazer JM, Tsuruda PR, Basbaum AI, Stucky CL, Jordt SE, Julius D (2007) The menthol receptor TRPM8 is the principal detector of environmental cold. Nature 448:204-208. CrossRef Medline

Brobeck JR (1997) Food intake as a mechanism of temperature regulation. Obes Res 5:641-645. CrossRef Medline

Cannon B, Nedergaard J (2009) Thermogenesis challenges the adipostat hypothesis for body-weight control. Proc Nutr Soc 68:401-407. CrossRef Medline

Caterina MJ (2007) Transient receptor potential ion channels as partici- 
pants in thermosensation and thermoregulation. Am J Physiol Regul Integr Comp Physiol 292:R64-R76. CrossRef Medline

Colburn RW, Lubin ML, Stone DJ Jr, Wang Y, Lawrence D, D'Andrea MR, Brandt MR, Liu Y, Flores CM, Qin N (2007) Attenuated cold sensitivity in TRPM8 null mice. Neuron 54:379-386. CrossRef Medline

Cornelissen G (2014) Cosinor-based rhythmometry. Theor Biol Med Model 11:16. CrossRef Medline

Dhaka A, Viswanath V, Patapoutian A (2006) Trp ion channels and temperature sensation. Annu Rev Neurosci 29:135-161. CrossRef Medline

Dhaka A, Murray AN, Mathur J, Earley TJ, Petrus MJ, Patapoutian A (2007) TRPM8 is required for cold sensation in mice. Neuron 54:371-378. CrossRef Medline

Feketa VV, Balasubramanian A, Flores CM, Player MR, Marrelli SP (2013) Shivering and tachycardic responses to external cooling in mice are substantially suppressed by TRPV1 activation but not by TRPM8 inhibition. Am J Physiol Regul Integr Comp Physiol 305:1040-1050. CrossRef Medline

Galgani J, Ravussin E (2008) Energy metabolism, fuel selection and body weight regulation. Int J Obes (Lond) 32 [Suppl. 7]:109-119. CrossRef Medline

Gavva NR, Davis C, Lehto SG, Rao S, Wang W, Zhu DX (2012) Transient receptor potential melastatin 8 (TRPM8) channels are involved in body temperature regulation. Mol Pain 8:36-44. CrossRef Medline

Gluck ME, Venti CA, Salbe AD, Votruba SB, Krakoff J (2011) Higher 24-h respiratory quotient and higher spontaneous physical activity in nighttime eaters. Obesity 19:319-323. CrossRef Medline

Hibi M, Masumoto A, Naito Y, Kiuchi K, Yoshimoto Y, Matsumoto M, Katashima M, Oka J, Ikemoto S (2013) Nighttime snacking reduces whole body fat oxidation and increases LDL cholesterol in healthy young women. Am J Physiol Regul Integr Comp Physiol 304:94-101. CrossRef Medline

Hosono T, Chen XM, Miyatsuji A, Yoda T, Yoshida K, Yanase-Fujiwara M, Kanousue K (2001) Effects of estrogen on thermoregulatory tail vasomotion and heat-escape behavior in freely moving female rats. Am J Physiol Regul Integr Comp Physiol 280:1341-1347. CrossRef Medline

Jaroslawska J, Chabowska-Kita A, Kaczmarek MM, Kozak LP (2015) Npvf: hypothalamic biomarker of ambient temperature independent of nutritional status. PLoS Genet 11:e1005287. CrossRef Medline

Jordt SE, McKemy DD, Julius D (2003) Lessons from peppers and peppermint: the molecular logic of thermosensation. Curr Opin Neurobiol 13: 487-492. CrossRef Medline

Kaiyala KJ, Ogimoto K, Nelson JT, Schwartz MW, Morton GJ (2015) Leptin signaling is required for adaptive changes in food intake, but not energy expenditure, in response to different thermal conditions. PLoS One 10: e0119391. CrossRef Medline

Knowlton WM, Daniels RL, Palkar R, McCoy DD, McKemy DD (2011) Pharmacological blockade of TRPM8 ion channels alters cold and cold pain responses in mice. PLoS One 6:e25894. CrossRef Medline

Landsberg L (2012) Core temperature: a forgotten variable in energy expenditure and obesity? Obes Rev 13:97-104. CrossRef Medline

Ma S, Yu H, Zhao Z, Luo Z, Chen J, Ni Y, Jin R, Ma L, Wang P, Zhu Z, Li L, Zhong J, Liu D, Nilius B, Zhu Z (2012) Activation of the cold-sensing TRPM8 channel triggers UCP1-dependent thermogenesis and prevents obesity. Mol Cell Biol 8:88-96. CrossRef Medline

McCoy DD, Knowlton WM, McKemy DD (2011) Scraping through the ice: uncovering the role of TRPM8 in cold transduction. Am J Physiol Regul Integr Comp Physiol 90089:1278-1287. CrossRef Medline

McCoy DD, Zhou L, Nguyen AK, Watts AG, Donovan CM, McKemy DD (2013) Enhanced insulin clearance in mice lacking TRPM8 channels. Am J Physiol Endocrinol Metab 305:78-88. CrossRef Medline

McKemy DD, Neuhausser WM, Julius D (2002) Identification of a cold receptor reveals a general role for TRP channels in thermosensation. Nature 416:52-58. CrossRef Medline

Melnyk A, Himms-Haggen J (1998) Temperature-dependent feeding: lack of role for leptin and defect in brown adipose tissue-ablated obese mice. Am J Physiol 274:1131-1135. Medline

Meyer CW, Ootsuka Y, Romanovsky AA (2017) Body temperature measurements for metabolic phenotyping in mice. Front Physiol 8:520. CrossRef Medline

Mishra SK, Tisel SM, Orestes P, Bhangoo SK, Hoon MA (2011) TRPV1lineage neurons are required for thermal sensation. EMBO J 30:582-593. CrossRef Medline

Morenilla-Palao C, Luis E, Fernández-Peña C, Quintero E, Weaver JL, Bayliss DA, Viana F (2014) Ion channel profile of TRPM8 cold receptors reveals a role of TASK-3 potassium channels in thermosensation. Cell Rep 8:1571-1582. CrossRef Medline

Morrison SF, Nakamura K (2011) Central neural pathways for thermoregulation. Front Biosci 16:74-104. CrossRef Medline

Nagashima K, Nakai S, Matsue K, Konishi M, Tanaka M, Kanosue K (2003) Effects of fasting on thermoregulatory processes and the daily oscillations in rats. Am J Physiol Regul Integr Comp Physiol 284:1486-1493. CrossRef Medline

Pan Y, Thapa D, Baldissera L Jr, Argunhan F, Aubdool AA, Brain SD (2017) Relevance of TRPA1 and TRPM8 channels as vascular sensors of cold in the cutaneous microvasculature. Pflugers Arch - Eur J Physiol 1-8. CrossRef

Peier AM, Moqrich A, Hergarden AC, Reeve AJ, Andersson DA, Story GM, Earley TJ, Dragoni I, McIntyre P, Bevan S, Patapoutian A (2002) A TRP channel that senses cold stimuli and menthol. Cell 108:705-715. CrossRef Medline

Pogorzala LA, Mishra SK, Hoon MA (2013) The cellular code for mammalian thermosensation. J Neurosci 33:5533-5541. CrossRef Medline

Romanovsky AA (2014) Skin temperature: its role in thermoregulation. Acta Physiol (Oxf) 210:498-507. CrossRef Medline

Seidell JC, Muller DC, Sorkin JD, Andres R (1992) Fasting respiratory exchange ratio and resting metabolic rate as predictors of weight gain: the Baltimore Longitudinal Study on Aging. Int J Obes Relat Metab Disord 16:667-674. Medline

Sittiracha T, McLachlan EM, Bells C (1987) The innervation of the caudal artery of the rat. Neuroscience 21:641-659. CrossRef Medline

Song K, Wang H, Kamm GB, Pohle J, Reis FC, Heppenstall P, Wende H, Siemens J (2016) The TRPM2 channel is a hypothalamic heat sensor that limits fever and can drive hypothermia. Science 353:1393-1398. CrossRef Medline

Tajino K, Matsumura K, Kosada K, Shibakusa T, Inoue K, Fushiki T, Hosokawa H, Kobayashi S (2007) Application of menthol to the skin of whole trunk in mice induces autonomic and behavioral heat-gain responses. Am J Physiol Regul Integr Comp Physiol 293:2128-2135. CrossRef Medline

Tajino K, Hosokawa H, Maegawa S, Matsumura K, Dhaka A, Kobayashi S (2011) Cooling-sensitive TRPM8 is thermostat of skin temperature against cooling. PLoS One 6:1-6. CrossRef Medline

Terrien J, Perret M, Aujard F (2011) Behavioral thermoregulation in mammals: a review. Front Biosci (Landmark Ed) 16:1428-1444. CrossRef Medline

Winter Z, Gruschwitz P, Eger S, Touska F, Zimmermann K (2017) Cold temperature encoding by cutaneous TRPA1 and TRPM8-carrying fibers in the mouse. Front Mol Neurosci 10:209. CrossRef Medline

World Health Organization (2000) Obesity: preventing and managing the global epidemic. WHO Tech Rep Ser 894:1-253. Medline

Yarmolinsky DA, Peng Y, Pogorzala LA, Rutlin M, Hoon MA, Zuker CS (2016) Coding and plasticity in the mammalian thermosensory system. Neuron 92:1079-1092. CrossRef Medline

Young AA, Dawson NJ (1982) Evidence for on-off control of heat dissipation from the tail of the rat. Can J Physiol Pharmacol 60:392-398. Medline

Zurlo F, Lillioja S, Esposito-Del Puente A, Nyomba BL, Raz I, Saad MF, Swinburn BA, Knowler WC, Bogardus C, Ravussin E (1990) Low ratio of fat to carbohydrate oxidation as predictor of weight gain: study of 24-h RQ. Am J Physiol 259:650-657. CrossRef Medline 